\title{
TAŞINMAZLARIN BIRLIKTE REHNİ (TMK m. 855)
}

\section{Fahri Erdem KAŞAK* / İpek GÜVENÇ**}

\section{$\ddot{O} Z$}

Taşıınmaz rehnine hâkim ilkelerden olan belirlilik ilkesine göre, bir alacağın tek bir taşınmaz üzerinde rehin hakkı kurularak temin edilmesi esastır. TMK m. 855 hükmünün öngördüğ̈̈ birlikte rehin kurumu ise bir alacağın birden çok taşınmaz ile güvence altına alınabilmesine imkân sağlar. Böylece uygulamada özellikle bankaların verdiği yüksek meblağlı kredileri birden fazla taşınmazı rehnederek temin edebilmek mümkün hâle gelmektedir. Bir alacağın birden çok taşınmaz rehnedilerek temin edilmesi hâlinde, her bir taşınmazın açıkça ve ayrı ayrı alacă̆ın ne kadarlık kısmını temin ettiğinin belirtilmesi kuraldır. Bununla birlikte istisnaen, alacağı temin edecek taşınmazlar aynı kişiye aitse veya taşınmazların malikleri müteselsil borçlu ise taşınmazların toplu olarak rehnedilebilmesi mümkündür. Bu ihtimalde her bir taşınmazın alacă̆ın ne kadarlık kısmını temin ettiği belirlenmez.

Anahtar Kelimeler: Taşınmaz rehni, birden çok taşınmazın rehnedilmesi, toplu rehin, paylı rehin, rehnin paraya çevrilmesi.

\section{GRUNDPFANDRECHT BEI MEHREREN GRUNDSTÜCKEN (Art. 798 ZGB)}

\section{ABSTRAKT}

Laut dem Grundsatz der Sicherheit, der zu den Grundsätzen der unbeweglichen Verpfändung gehört, ist es die Regel, dass eine Forderung durch die Feststellung des Verpfändungsrechts auf eine einzige Grundstück erbracht wird. Das in Art. 855 tZGB vorgesehene Grundpfandrecht bei mehreren Grundstücken ermöglicht die Sicherung einer Forderung bei mehreren Grundstücken. So ist es in der Praxis möglich, vor allem von Banken gewährte Unsumme von Krediten zu erhalten, indem mehrere Grundstücke verpfändet werden. Wenn eine Forderung durch Verpfändung von mehr als ein Grundstück erbracht wird, ist das Prinzip ausdrücklich und getrennt zu bestimmen, wie viel jedes Grundstück mit einem bestimmten Teilbetrag des Forderungsrechts belastet wird. Es ist jedoch ausnahmsweise möglich, die Grundstücken kollektiv verpfändet werden kann, wenn die Grundstücke dem nämlichen Eigentümer gehören oder im Eigentum solidarisch verpflichteter Schuldner stehen. In diesem Fall ist es nicht erforderlich zu bestimmen, in welchem Umfang jedes Grundstück den Teil der Forderung ausmacht.

Schlüsselwörter: Grundpfandrecht, Grundpfandrecht bei mehreren Grundstücken, Gesamtpfandrecht, Pfandhaftverteilung, Pfandverwertung.

\footnotetext{
* Arş. Gör. Dr., Ankara Hacı Bayram Veli Üniversitesi Hukuk Fakültesi Medenî Hukuk Anabilim Dalı. fahri.kasak@hbv.edu.tr

**Ankara Barosu Avukatı, Ankara Üniversitesi Sosyal Bilimler Enstitüsü Özel Hukuk Anabilim Dalı Yüksek Lisans Öğrencisi. guvencipek@gmail.com
}

Yayın Kuruluna Ulaştığı Tarih $\quad$ : 15.02.2019

Yayınlanmasının Uygun Görüldüğü Tarih : 22.02.2019 


\section{GíRIŞ}

Taşınmaz rehni TMK m. 850 vd. hükümlerinde düzenlenmiştir. Taşınmaz rehnine hâkim ilkelerden olan belirlilik ilkesinin ${ }^{1}$ iki yönü bulunmaktadır: Bunlardan ilki teminat altına alınacak alacağın, ikincisi ise teminat teşkil edecek taşınmazın belirlenmiş olmasıdır ${ }^{2}$. Bu bakımdan belirlilik ilkesi, hem teminat altına alınacak alacağın hem teminat teşkil edecek taşınmazın bir bütün ${ }^{3}$ olarak rehne konu olmasını gerektirir. Öte yandan TMK m. 855 (Art. 798 ZGB) hükmünün açık icazeti karşısında aynı alacağı temin etmek üzere, birden çok taşınmaz üzerinde rehin kurulabilmesi belirlilik ilkesine (Bestimmtheit, Spezialitätsprinzip, le principe de la spécialité) aykırılık teşkil etmez ${ }^{4}$. Nitekim TMK m. 854-855 hükümlerinin üst başlı̆̆ "belirli olma", TMK m. 855 düzenlemesinin kenar başlığı ise "taşınmaz birden çok ise"dir.

Rehnin konusunu oluşturacak taşınmazların ayrı ayrı ve açıkça belirtilmeleri hâlinde birden çok taşınmaz rehnedilmesinden veya -daha kısa bir ifadeyle- birlikte rehinden söz edilmektedir ${ }^{5}$. TMK m. 855 uyarınca birlikte rehin iki farklı şekilde kurulabilir: Toplu rehin olarak anılan ve TMK m. 855/I hükmüyle düzenlenen ilk hâlde; rehin yükü paylaştırılmadan, rehin konusu bütün taşınmazlar üzerinde rehin tesis edilir. Paylı rehin olarak

\footnotetext{
${ }^{1}$ OĞUZMAN/SELİÇi̇/OKTAY-ÖZDEMİR, N 3199.

${ }^{2}$ TUOR/SCHNYDER/SCHMID/JUNGO, § 112 N 21 vd., 29 vd.; GÜNEL, s. 248; ACAR, Rehin, N 73 vd.; ACAR, Belirlilik, s. 162 vd.; OĞUZMAN/SELIÇİ/OKTAY-ÖZDEMİR, $\mathrm{N}$ 3201. Bu bağlamda sınırlı tip ve belirlilik ilkelerinin bir sonucu olarak, bir kişinin sahip olduğu ya da olacağı tüm taşınmazlar üzerinde tek bir alacak için topluca rehin tesis etmesinin mümkün olmadığ1 yönünde bkz. TUOR/SCHNYDER/SCHMID/JUNGO, § $112 \mathrm{~N}$ 29; DÜRR, Art. 798 N 14; KÖPRÜLÜ/KANETİ, s. 290; SAYMEN/ELBIR, s. 581; TEKINAY, s. 74; SEROZAN, s. 319; KURŞAT, s. 393.

${ }^{3}$ OĞUZMAN/SELİÇİ/OKTAY-ÖZDEMIR, N 3213; ACAR, Belirlilik, s. 163.

${ }^{4}$ DÜRR, Art. 798 N 1-2; SCHMID-TSCHIRREN (2015), Art. 798 N 1; KÖPRÜLÜ/KANETİ, s. 290-291; OĞUZMAN/SELIÇİ/OKTAY-ÖZDEMIR, N 3214; ACAR, Belirlilik, s. 242; AYDIN ÜNVER, s. 85. Belirlilik ilkesine dair kapsamlı açıklamalar için bkz. SARI, s. 963 vd. Birden çok taşınmazın tek bir alacak hakkının teminatı olarak rehinle yüklenebilmesi, çeşitli ekonomik gerekçelerle kabul edilmiştir. Borç ilişkilerinde alacak miktarları kimi zaman üzerinde rehin kurulması düşünülen taşınmazın değerini aşmaktadır. Bu durumda, bir tek taşınmazın değeri, borç ilişsisindeki alacağı temin etmeye yetmemektedir. Özellikle bankaların verdikleri kredileri taşınmaz rehni ile teminat altına almak istemeleri ve kredi miktarlarının yüksek meblağlara ulaşması dolayısıyla bu tarz hâllere uygulamada sıkça rastlanılmaktadır.

${ }^{5}$ KURŞAT, s. 393 vd.; ÖZER, s. 14. Şu hâlde TMK m. 855 çerçevesinde birden çok taşınmazın, tek bir alacağı temin etmesi söz konusudur. Bu bakımdan taşınmazların, farklı alacaklar için tek tek rehnedilmesi ihtimalinin TMK m. 855 hükmünün kapsamına girmediği yönünde bkz. DÜRR, Art. 798 N 15-16.
} 
adlandırılan ve TMK m. 855/II-III hükmünde düzenlenen ikinci hâlde ise; her bir taşınmaz, alacağın belirli bir kısmı için rehin ile yüklenir. TMK m. 855 hükmüne göre kural paylı rehin olmasına rağmen ${ }^{6}$, çalışmamızda TMK m. 855 hükmündeki sıra benimsenmiş ve ilk olarak toplu rehin, sonrasında paylı rehin irdelenmiştir.

\section{§ 1. TOPLU REHIN}

\section{Genel Olarak}

TMK m. 855/I ve TST m. 32/I/a-b düzenlemeleri çerçevesinde birden çok taşınmazın aynı borç için rehnedilmesi, ögretide ağırlıklı olarak "toplu rehin" (Gesamtpfand, Gesamtpfandrecht, droit de gage collectif) şeklinde adlandırılmaktadır". Ayrıca "ortak rehin", "müşterek rehin", "kollektif rehin" $" 10$ veya "müteselsil rehin" $" 11$ kavramlarına da rastlanmaktadır.

\section{Toplu Rehnin Konusu}

\section{A. Genel Olarak}

TMK m. 855 hükmü, aynı alacak için birden fazla "taşınmaz" üzerinde rehin kurulmasından bahsetmektedir. Dolayısıyla, birlikte rehnin konusunu esas olarak taşınmaz eşyanın teşkil edeceği şüphesizdir. TMK m. 853 hükmü ise, yalnızca tapuya kayıtlı taşınmazlar üzerinde rehin kurulabileceğini düzenlemiştir. Dolayısıyla ipotek sözleşmesi ve tapuya tescilin yapılamayacağ1

\footnotetext{
${ }^{6}$ BGE 138 III 186-187 E. 4.2 ("En principe, la mise en gage de plusieurs immeubles pour garantir une seule créance implique une répartition de la garantie sur les divers immeubles, chacun de ceux-ci ne répondant alors que pour la somme fixée lors de la répartition."); MARCHAND, Art. 798 N 1-2; LEEMANN, Art. 798 N 1; AKIPEK/AKINTÜRK/ATEŞ, s. 762; ACAR, Rehin, N 95; ACAR, Belirlilik, s. 251; GÜNEL, s. 248; ÇETİNER, s. 199; HELVACI, s. 212; KURŞAT, s. 394; GÖKTÜRK, s. 1037-1038; AYDIN ÜNVER, s. 88; KUNTALP, s. 266-267.

7 YHGK, T. 27.11.2002, E. 2002/12-823, K. 2002/1020; Yarg. 8. HD, T. 31.12.2013, E. 2013/21690, K. 2013/20428; Yarg. 12. HD, T. 23.11.2001, E. 2001/17448, K. 2001/19796; Yarg. 12. HD, T. 18.04.2002, E. 2002/6829, K. 2002/8052; DÜRR, Art. 798 N 12, 48 vd.; SCHMID/HÜRLIMANN-KAUP，N 1519; KÖPRÜLÜ/KANETİ，s. 291; OĞUZMAN/ SELIÇİ/OKTAY-ÖZDEMIR, N 3220; KUNTALP， s. 266，270; SARI，s. 1004-1005; TEKINAY, s. 74; HATEMİ/SEROZAN/ARPACI, s. 725; HELVACI, s. 212; ÖZER, s. 26; ÇETINER, s. 199; SİRMEN, s. 586; GÜNEL, s. 248.

${ }^{8}$ AKİPEK/AKINTÜRK/ATEŞ, s. 762.

${ }^{9}$ DAVRAN, s. 28; GÖKTÜRK, s. 1038; GÜRSOY/EREN/CANSEL, s. 1036.

${ }^{10}$ SAYMEN/ELBİR, s. 583; GÜRSOY, s. 8.

${ }^{11}$ KURŞAT, s. 399, 403 vd.; ACAR, Rehin, N 95; SEROZAN, s. 319; BENGİSU, s. 1883; ACAR, Belirlilik, s. 250.
} 
tapuya kayıtlı olmayan taşınmazlar, rehnin konusu olamaz ${ }^{12}$.

TMK m. 998 hükmünde tapuya kaydedilecek taşınmazlar olarak sayılan arazi, taşınmazlar üzerindeki bağımsız ve sürekli haklar ile kat mülkiyetine konu olan bağımsız bölümler üzerinde toplu rehin kurulabileceğine şüphe bulunmamaktadır ${ }^{13}$. Nitekim TMK m. 704 hükmünde de taşınmaz mülkiyetinin konusu olarak arazi, tapu kütüğünde ayrı sayfaya kaydedilen bağımsız ve sürekli haklar ile kat mülkiyeti kütüğüne kayıtlı bağımsız bölümler sıralanmıştır. Toplu rehnin konusunu oluşturacak taşınmazların, aynı türden olmasina gerek yoktur ${ }^{14}$.

\section{B. Paylı Mülkiyet Payları}

TMK m. 704 hükmünü karşılayan Art. 655/II ZGB hükmünde, yukarıda zikredilmiş olan taşınmaz türlerine ek olarak paylı mülkiyete tâbi taşınmazlardaki paylı mülkiyet payları da sayılmıştır ${ }^{15}$. Gerçekten de paylı mülkiyet konusu taşınmazların da rehnin konusunu oluşturabileceği şüphesizdir. Ancak burada paylı mülkiyet konusu taşınmazın tamamının rehnedilmesinin toplu rehin teşkil etmeyeceğini belirtmek gerekir. $\mathrm{Bu}$

12 TUOR/SCHNYDER/SCHMID/JUNGO, $§ 112$ N 28; OĞUZMAN/SELİÇI/OKTAYÖZDEMİR, N 3211; SARI, s. 992; GÜRSOY, s. 4; GÜRSOY/EREN/CANSEL, s. 1031; HATEMI/SEROZAN/ARPACI, s. 725-726; ACAR, Rehin, N 74; ACAR, Belirlilik, s. 242; AYDIN ÜNVER, s. 86.

${ }^{13}$ SARI, s. 992-993; ÖZER, s. 19. KMK m. 58/III hükmü çerçevesinde devre mülk hakk1 üzerinde rehin hakkının kurulabileceği ve bu bakımdan devre mülk hakkının da toplu rehnin konusunu teşkil edebileceği yönünde bkz. SARI, s. 993-994. Taşınmaz rehninin konusuna nelerin girdiği hususundaki açılamalar için bkz. SARI, s. 994-1003. İsviçre hukukunda Art. 74/II BGBB hükmü gereğince, tarımsal taşınmazlar ile tarımsal olmayan taşınmazların birlikte toplu rehnin konusunu oluşturamayacağ 1 yönünde bkz. DÜRR, Art. 798 N 24, 52; SCHMID-TSCHIRREN (2015), Art. 798 N 3a; SCHMID-TSCHIRREN (2016), Art. 798 N 8; MARCHAND, Art. 798 N 8; TUOR/SCHNYDER/SCHMID/JUNGO, § 112 N 32; HRUBESCH-MILLAUER/GRAHAM-SIEGENTHALER/ ROBERTO, N 09.72; SCHMID/ HÜRLIMANN-KAUP, N 1519, 1525. İlgili hükümde açıça toplu rehnin (Gesamtpfand) caiz olmadığı belirtildiği için kanaatimizce paylı rehin bakımından böyle bir sınırlama söz konusu olamaz.

${ }^{14}$ DÜRR, Art. 798 N 49. Şu hâlde bir arazinin, bir bağımsız ve sürekli hak ile veya kat mülkiyetine konu bağımsız bölüm ile birlikte rehnedilebilmesi mümkündür.

${ }^{15}$ HRUBESCH-MILLAUER/GRAHAM-SIEGENTHALER/ROBERTO, N 09.64; SCHMIDTSCHIRREN (2016), Art. 798 N 3; SCHMID-TSCHIRREN (2015), Art. 798 N 3. İsviçre hukukunda kat mülkiyeti, paylı mülkiyet çerçevesinde çözümlendiği için hükümde ayrıca kat mülkiyetine tâbi bağımsız bölümler sayılmamıştır. Nitekim İsviçre hukukunda kat mülkiyetine tâbi bağımsız bölümlerin, toplu rehnin konusunu teşkil edebilmesi Art. 655/II/4 ZGB hükmüne dayandırılmaktadır. Bu hususta bkz. SCHMID-TSCHIRREN (2015), Art. 798 N 6a; HRUBESCH-MILLAUER/GRAHAM-SIEGENTHALER/ROBERTO, N 09.73; DÜRR, Art. 798 N 62. 
bakımdan tüm paydaşların birlikte hareket ederek taşınmazın bütünü üzerinde ehin tesis etmesi hâlinde toplu rehin uygulama alanı bulmaz ${ }^{16}$. Zira burada artık birden çok sayıda taşınmazın değil, tek bir taşınmazın rehni söz konusu olur ${ }^{17}$. Bununla birlikte paylı mülkiyete tâbi bir taşınmazın tamamının veya paylarının bir kısmının, toplu rehnin konusunu teşkil etmeye müsait başka bir taşınmazla rehni de toplu rehin olarak değerlendiriliri ${ }^{18}$. Nitekim TST m. 32/I/a-b hükümleri de bu sonucu aç1kça öngörmüştür.

TMK m. 692/I hükmü çerçevesinde paylı mülkiyet konusu taşınmazın tamamının rehnedilebilmesi tüm paydaşların kabulünü gerektirir ${ }^{19}$. Öte yandan her bir paydaş, TMK m. 688/III ve m. 857/I düzenlemelerinde açıkça öngörüldüğ̈ üzere kendi payını rehnedebilir ${ }^{20}$. Şu hâlde her bir paydaşın kendi payını TMK m. 855 uyarınca toplu rehne konu edebileceği açıktır ${ }^{21}$. Ancak paylardan asgarî bir tanesi üzerinde rehin hakkı kurulmuşsa artık paylı taşınmazın bir bütün olarak rehnedilebilmesi, TMK m. 692/II ve m. 857/II uyarınca mümkün gözükmemektedir ${ }^{22}$. Buna karşılık önceden taşınmazın tamamı üzerinde rehin tesis edilmiş olduğu hâlde taşınmaz üzerindeki payın sonradan başka bir rehne konu edilebilmesine mani bulunmamaktadır ${ }^{23}$.

\section{Elbirliğ̣i Mülkiyeti}

Elbirliği mülkiyeti bakımından TMK m. 702/II hükmü, tasarruf

${ }^{16}$ KUNTALP, s. 274; GÜRSOY, s. 7; KURŞAT, s. 396.

${ }^{17}$ SCHMID-TSCHIRREN (2015), Art. 798 N 4; FASEL, Art. 798 N 3; DÜRR, Art. 798 N 56; LEEMANN, Art. 798 N 27; KURŞAT, s. 396; KUNTALP, s. 274; ÇETINER, s. 200; GÜRSOY, s. 7.

${ }^{18}$ SCHMID-TSCHIRREN (2015), Art. 798 N 3; SİRMEN, s. 587; KURŞAT, s. 395-396; GÜRSOY, s. 6-7.

19 SARI, s. 993.

${ }^{20}$ SCHMID/HÜRLIMANN-KAUP, N 1522; LEEMANN, Art. 798 N 25 vd.; TEKINAY, s. 74; SARI, s. 993; ACAR, Belirlilik, s. 42; KÖPRÜLÜ/KANETİ, s. 290.

${ }^{21}$ SCHMID-TSCHIRREN (2015), Art. 798 N 3.

${ }^{22}$ HRUBESCH-MILLAUER/GRAHAM-SIEGENTHALER/ROBERTO, N 09.73; SCHMID/ HÜRLIMANN-KAUP， N 1523; OĞUZMAN/SELİÇ̇/OKTAY-ÖZDEMIR， N 3211; SEROZAN, s. 318. Üzerinde rehin kurulmuş payların rehin alacaklıları, eğer onay verirlerse paylı malın tamamının rehninin mümkün olabileceği yönünde bkz. bkz. BGE 113 II 161162 E. 1d ("Voraussetzung ist jedoch, dass einer solchen Abmachung auch die Gläubiger von Pfandrechten an den einzelnen Anteilen zustimmen."); GÜRSOY, s. 7; SCHMID/ HÜRLIMANN-KAUP, N 1523; HRUBESCH-MILLAUER/GRAHAM-SIEGENTHALER/ ROBERTO, N 09.74.

${ }^{23}$ DÜRR, Art. 798 N 63; HRUBESCH-MILLAUER/GRAHAM-SIEGENTHALER/ ROBERTO, N 09.73; SCHMID/HÜRLIMANN-KAUP, N 1522; OĞUZMAN/SELIÇİ/ OKTAY-ÖZDEMIR, N 3211. 
işlemlerinde ortakların oybirliğiyle karar almasını aramıştır. Nitekim TMK m. 857/III hükmü de elbirliği mülkiyetine konu bir taşınmazın, tüm maliklerinin rızasıyla ve sadece bir bütün olarak rehnedilebileceğini düzenlemiştir ${ }^{24}$. Esasen elbirliği mülkiyetinde ayrı ve birbirinden bağımsız paylar mevcut olmadığından birden fazla taşınmazdan bahsedilmez ${ }^{25}$. Dolayısıyla elbirliği mülkiyetine konu taşınmaz üzerinde rehin tesis edildiğinde birlikte rehin doğmaz, aksine rehnin konusunu tek bir taşınmaz oluşturur ${ }^{26}$. Bu bakımdan üzerinde elbirliği mülkiyeti bulunan bir taşınmazın, toplu rehnin konusunu oluşturabilecek başka bir taşınmazla beraber rehni hâlinde toplu rehin söz konusu olabilir. Öte yandan, elbirliği ile malik olan kişilerin, elbirliği mülkiyetine konu birden fazla taşınmaz üzerinde aynı alacağa teminat oluşturmak amaciyla rehin kurması ise toplu rehin teşkil eder ${ }^{27}$.

\section{Madenler}

HernekadareTMK m. 911 hükmü madenleri taşınmazlararasında saymış olsa da TMK'de bu yönde bir düzenleme yer almamıştır. eTMK döneminde çıkarılmış olan MadK m. 42 hükmü; maden işletme ruhsatına sahip olanların, maden için yapmış olduğu veya ileride yapacağ borçlanmaları teminat altına almak amacıyla maden üzerinde ipotek kurabileceğini düzenlemiştii ${ }^{28}$. MadK m. 45 hükmü ise eTMK'nin ipoteğe ilişkin hükümlerinin maden ipoteklerine de uygulanacağını düzenlemiştir. Şüphesiz eTMK'ye yapılan söz konusu atıf; TMKYK m. 21 hükmü uyarınca, onu ilga eden TMK' ye yapılmış sayılmaktadır. Bu durumda, TMK m. 855 hükmünün maden ipotekleri açısından da geçerli olacağı açıktır ${ }^{29}$. Sonuç olarak, maden için yapılmış veya yapılacak masrafları teminat altına almak amacıyla bir maden ile başka bir taşınmaz üzerinde TMK m. 855 uyarınca birlikte rehin kurulabilmesi mümkündür ${ }^{30}$. Ancak aynı alacağ1 teminat altına almak maksadıyla birden fazla maden rehin ile yüklenemez ${ }^{31}$.

\footnotetext{
${ }^{24}$ OĞUZMAN/SELİÇI/OKTAY-ÖZDEMİR, N 3211; KÖPRÜLÜ/KANETİ, s. 290; TEKİNAY, s. 74; SARI, s. 993; SEROZAN, s. 318.

${ }^{25}$ GÜRSOY, s. 7; KURŞAT, s. 396.

${ }^{26}$ DÜRR, Art. 798 N 91; LEEMANN, Art. 798 N 19; ÖZER, s. 21; KURŞAT, s. 396.

${ }^{27}$ ÖZER, s. 21.

${ }^{28} \mathrm{Bu}$ sebeple bir başkasının borcunu temin etmek üzere maden ipoteği kurulabilmesi mümkün değildir. Benzer şekilde maden ipoteği, -hükümde de zikredildiği üzere- maden için yapılmış veya yapılacak masrafları teminat altına almak üzere kurulabildiğinden daha dar bir uygulama alanına sahiptir. Bu yöndeki açıklamalar için bkz. TOPALOĞLU, s. 313-314.

${ }^{29}$ GÜRSOY, s. 6; KURŞAT, s. 398; ÖZER, s. 22.

${ }^{30}$ SARI, s. 992-993; KURŞAT, s. 398; GÜRSOY, s. 5-6.

${ }^{31}$ ÖZER, s. 22-23.
} 


\section{E. Toplu Rehne Konu Olamayacak Şeyler}

\section{Gemiler}

TTK m. 1021/I hükmü uyarınca gemi siciline kayıtlı gemiler açısından birlikte rehin kurulması mümkündür. TTK kapsamında özel bir düzenlemeye tâbi tutulmuş olan gemilerin birlikte rehni konusunda TMK hükümleri uygulama alanı bulmaz. Ayrıca TMK kapsamında taşınır eşya sayılan gemilere, yalnızca taşınmaz eşya bakımından geçerli olan TMK m. 855 hükmünün uygulanabilmesi mümkün değildir ${ }^{32}$. Başka bir deyişle, aynı alacağı teminat altına almak amacıyla birden çok gemi üzerinde ipotek kurulması durumunda TMK m. 855 düzenlemesine değil, TTK hükümlerine başvurulur ${ }^{33}$.

\section{Hava Araçları}

TSHK m. 72 hükmünde bir alacak için birden çok hava aracının birlikte ipotek edilebileceği düzenlenmiştir. Anılan hükümle özel bir düzenleme öngörüldüğü için TMK m. 855 hükmü çerçevesinde toplu rehin uygulama alanı bulamaz ${ }^{34}$. Ayrıca TSHK m. 65 hükmü uyarınca, aksi belirtilmedikçe hava araçlarının taşınır eşya olarak kabul edildiğini vurgulamakta da fayda vardir.

\section{Toplu Rehnin Şartları}

Toplu rehin, TMK m. 855/I hükmü uyarınca iki farklı şekilde söz konusu olabilir: Aynı borç için rehnedilecek birden çok taşınmazın ya aynı malike ya da müteselsil borçlulara ait olması gerekir. Bu şartlardan birinin mevcut olması toplu rehnin kurulması için yeterlidir ${ }^{35}$. Anılan şartlardan asgarî biri sağlanamazsa toplu rehnin kurulamayacağ 1 açıtır ${ }^{36}$. Bu şartlar sağlansa dahi tarafların toplu rehin kurma yönündeki iradelerinin açıç̧a anlaşmas1 gerekir ${ }^{37}$. Zira TMK m. 855/I hükmü; istisnaî bir nitelik taşımakta

\footnotetext{
${ }^{32}$ KURŞAT, s. 396-398; ÖZER, s. 23.

${ }^{33}$ KURŞAT, s. 396-398; ÖZER, s. 23. Aksi kanaatte bkz. GÜRSOY, s. 6.

${ }^{34}$ ÖZER, s. 25.

${ }^{35}$ SCHMID-TSCHIRREN (2015), Art. 798 N 4a; LEEMANN, Art. 798 N 17 vd.

${ }^{36}$ SCHMID-TSCHIRREN (2015), Art. 798 N 4; TUOR/SCHNYDER/SCHMID/JUNGO, § 112 N 33; KÖPRÜLÜ/KANETİ, s. 292; HATEMİ/SEROZAN/ARPACI, s. 725.

${ }^{37}$ YHGK, T. 27.11.2002, E. 2002/12-823, K. 2002/1020 (“Ne var ki bu şartlar bulunsa bile kurulacak rehinin toplu rehin olması zorunlu değildir. ... Bu bakımdan rehinin toplu olduğu kuruluş sözleşmesinde belirtilmelidir."); FASEL, Art. 798 N 5; SCHMID-TSCHIRREN (2016), Art. 798 N 9; SCHMID-TSCHIRREN (2015), Art. 798 N 10; LEEMANN, Art. 798 N 28; HRUBESCH-MILLAUER/GRAHAM-SIEGENTHALER/ROBERTO, N 09.70; HELVACI, s. 218; ÇETINER, s. 204; ACAR, Belirlilik, s. 253; AKİPEK/AKINTÜRK/ ATEŞ, s. 762; ACAR, Rehin, N 95.
} 
olup birden çok taşınmazın rehninde kural, rehin yükünün taşınmazlara paylaştırılmasıdır. Ayrıca toplu rehin; taşınmaz malikine, paylı rehne göre daha fazla bir sorumluluk yüklediği ve malikin taşınmazı ile kredi alabilmesini veya taşınmazını satabilmesini ciddi ölçüde zorlaştırdığı için de açıkça kararlaştırılmış olmalıdır ${ }^{38}$. Bununla birlikte alacaklı bakımından toplu rehin, paylı rehne göre şüphesiz daha güvenli bir teminat teşkil eder ${ }^{39}$.

Anılan hükümde açıkça zikredilmemekle birlikte, toplu rehnin kurulabilmesi için gerekli çeşitli ek şartlar da aşağıda ele alınmıştır. Toplu rehnin şartları mevcut değilse tarafların kurdukları birlikte rehin, paylı rehin olarak değerlendirilir ${ }^{40}$. Toplu rehnin şartları mevcut olsa bile taraflar toplu rehin kurmayabilir ve bunun yerine paylı rehin ya da her bir taşınmaz üzerinde tek tek rehin hakk1 da kurabilirit ${ }^{41}$.

\section{A. Rehin ile Yüklenen Taşınmazların Aynı Kişiye veya Müteselsil Borçlulara Ait Olması}

TMK m. 855/I hükmü, toplu rehnin kurulabilmesi için rehnedilecek birden çok taşınmazın ya aynı malike ya da müteselsil borçlulara ait olmasını aramaktadır. Şayet anılan şartlar sağlanamazsa, sınırlı sayı ve tipe bağlılık ilkeleri gereği TMK m. 855 hükmü uygulama alanı bulamaz ve toplu rehin kurulamaz ${ }^{42}$.

\section{Taşınmazların Malikinin Aynı Kişi Olması}

Toplu rehne konu taşınmazların maliki, aynı gerçek ya da tüzel kişi

\footnotetext{
${ }^{38}$ DÜRR, Art. 798 N 170; SCHMID-TSCHIRREN (2015), Art. 798 N 10; LEEMANN, Art. 798 N 14; AKİPEK/ AKINTÜRK/ATEŞ, s. 762; GÜRSOY/EREN/CANSEL, s. 1037; HELVACI, s. 218; KURŞAT, s. 403-404; DAVRAN, s. 28; BENGİSU, s. 1884; KUNTALP, s. 272.

${ }^{39}$ YHGK, T. 27.11.2002, E. 2002/12-823, K. 2002/1020 ("Eş söyleyişle toplu rehin hak sahibine güvencenin rehinli taşınmazlar arasında bölünmesine klyasla daha fazla güvence sağlar."); SCHMID-TSCHIRREN (2015), Art. 798 N 10; HRUBESCH-MILLAUER/ GRAHAM-SIEGENTHALER/ROBERTO, N 09.71; LEEMANN, Art. 798 N 13; GÜRSOY, s. 12; HELVACI, s. 214; GÜRSOY/EREN/CANSEL, s. 1036-1037; KÖPRÜLÜ/KANETİ, s. 291, 293; DAVRAN, s. 28; KUNTALP, s. 268, 272.

${ }^{40}$ YHGK, T. 27.11.2002, E. 2002/12-823, K. 2002/1020 (“Kuruluş sözleşmesinde toplu rehin olgusunun açıçca belirtilmemiş olması, dolayısıyla da tarafların "toplu rehin" kurma yolunu seçmemiş olmaları halinde ikinci bir yol "aynı alacak için birden fazla taşınmazın rehin yükünün rehnedilecek taşınmazlar arasında paylaştırılıp, dağıtılması"”dır."); DÜRR, Art. 798 N 10.

${ }^{41}$ SCHMID-TSCHIRREN (2015), Art. 798 N 10; FASEL, Art. 798 N 6; GÜRSOY, s. 21; KUNTALP, s. 273.

${ }^{42}$ ACAR, Belirlilik, s. 252.
} 
olabilir ${ }^{43}$. Bu noktada; taşınmazı rehinle yüklenecek kişinin, teminat altına alınan borçtan şahsen sorumlu olmasına veya borçlunun, taşınmazların maliki olmasına kural olarak gerek yoktur ${ }^{44}$. Ancak böyle bir durumda, taşınmazlar üzerinde yalnızca ipotek veya ipotekli borç senedi türünde rehin tesis edilebilir. Gerçekten TMK m. 881/II ve m. 901/I çerçevesinde üçüncü bir kişi de kendi taşınmazını, borçlunun borcunu temin etmek üzere ipotek veya ipotekli borç senedi türlerinde rehnedebilir. Ancak TMK m. 907/I düzenlemesine göre irat senedinde borçlu ile taşınmazı rehnedilen malik aynı kişi olmak zorundadır.

\section{Taşınmazların Müteselsil Borçlu Maliklere Ait Olması}

TMK m. 855/I hükmü çerçevesinde toplu rehnin konusunu, ayn1 borçtan müteselsil sorumlu olan borçluların taşınmazları da oluşturabilir. Diğer bir anlatımla, borçtan müteselsil sorumlu olmayan farklı kişilerin maliki olduğu taşınmazlar üzerinde toplu rehin tesis edilemez. Öte yandan, bu hâlde taşınmazlar üzerinde paylı rehin kurulmasına bir engel bulunmamaktadır.

TBK m. 162 hükmü uyarınca müteselsil borçluluk, birden fazla borçlunun her birinin alacaklıya karşı borcun bütününden sorumlu olması hâlinde ortaya çıar. Toplu rehnin kurulabilmesi için müteselsil borç, tapu memuruna ispatlanmalıdır ${ }^{45}$. Müteselsil kefalet (TBK m. 586) de, müteselsil borçluluk gibi toplu rehin kurulmasına imkân verir ${ }^{46}$.

\section{B. Alacağın Aynı Olması}

TMK m. 855 hükmüne göre toplu rehin, sadece aynı alacağı teminat altına almak amacıyla kurulabilir. Aynı hukukî ilişkiden ve kaynaktan doğmuş alacak, aynı alacak olarak kabul edilir ${ }^{47}$. Cari hesap sözleşmesinden tek bir alacak hakk1 doğduğu için bunu temin etmek amacıyla toplu rehin tesis edilebilir ${ }^{48}$.

\footnotetext{
43 ÖZER, s. 29.

${ }^{44}$ DÜRR, Art. 798 N 17; KÖPRÜLÜ/KANETİ, s. 292; ÖZER, s. 29.

${ }^{45}$ SCHMID-TSCHIRREN (2015), Art. 798 N 6; LEEMANN, Art. 798 N 29; ACAR, Belirlilik, s. 255.

${ }^{46}$ DÜRR, Art. 798 N 105; SCHMID-TSCHIRREN (2016), Art. 798 N 7; LEEMANN, Art. 798 N 22; SCHMID-TSCHIRREN (2015), Art. 798 N 6; HELVACI, s. 217 dn. 25; DAVRAN, s. 28; GÜRSOY, s. 15; KUNTALP, s. 275; BENGISU, s. 1883-1884; ÇETINER, s. 203; ÖZER, s. 31; ACAR, Belirlilik, s. 255. Kefalet sözleşmesinin, en geç toplu rehnin tescili anına kadar yapılması gerektiği yönünde bkz. GÜRSOY, s. 15.

${ }^{47}$ GÜRSOY, s. 13. Yazar; örnek olarak biri sebepsiz zenginleşmeden, diğeri ise taraflar arasındaki sözleşmeden doğan alacağın, aynı alacak şartını sağlayamaması nedeniyle TMK m. 855 hükmü çerçevesinde toplu rehne vücut vermeyeceğini belirtmektedir.

${ }^{48}$ GÜRSOY, s. 13; KURŞAT, s. 409; ÇETINNER, s. 200.
} 
Alacağın aynı olması, kural olarak alacaklı tarafın tek kişiden oluşması anlamına gelir ${ }^{49}$. Bununla birlikte her ne kadar müteselsil alacaklılık, kısmî alacaklılık veya elbirliği hâlinde alacaklılık hâllerinde alacaklı taraf birden fazla kişiden meydana gelse de tek bir alacak hakk1 mevcuttur ${ }^{50}$.

Toplu rehnin kurulması, birden çok alacak hakkının mevcut olduğu anlamına gelmez ${ }^{51}$. Rehin hakk1 sahibinin, sadece tek bir hakkı bulunduğu için rehin hakkının tamamı üzerinde tasarruf edebilir ${ }^{52}$. Bu sebeple toplu rehin hakk1 sahibi, hakkını farklı kişilere temlik edemez ${ }^{53}$ veya temlik hakkını sadece bazı taşınmazlar bakımından kullanamaz ${ }^{54}$.

\section{Teminatın Bölünmemesi}

Toplu rehinde rehin ile yüklenen taşınmazların her biri, teminat altına alınan alacağın tamamından sorumludur. Bu bakımdan taşınmazlar üzerindeki rehin hakkı bir bütünlük teşkil eder ve bölünemez ${ }^{55}$. Nitekim TST m. 32/I/a hükmü gereğince rehin konusu taşınmazların hepsinin tapu sicillerine alacak miktarının tümü yazılır.

Toplu rehin sahibine tanınan alacak hakkı, yeknesak nitelik arz ettiği için farklı kişilere devredilemez ${ }^{56}$. Benzer şekilde rehin hakkı sahibinin, devir hakkını sadece bazı taşınmazlar bakımından kullanabilmesi de mümkün değildir ${ }^{57}$. Şu hâlde toplu rehnin alacaklısı, alacak hakkını bir bütün olarak devredebilecek ve toplu rehne konu tüm taşınmazlar üzerindeki rehin hakk1

\footnotetext{
${ }^{49}$ YHGK, T. 27.11.2002, E. 2002/12-823, K. 2002/1020 (“Toplu rehin yalnız bir alacaklı yararına kurulabilir ...”); KÖPRÜLÜ/KANETİ, s. 293; ÖZER, s. 34.

${ }^{50}$ DÜRR, Art. 798 N 70; GÜRSOY, s. 14; ÖZER, s. 34; ÇETINER, s. 200.

${ }^{51}$ BGE 126 III 34 E. 2 ("Les 49 lots PPE litigieux appartiennent au même propriétaire et sont grevés de la même cédule hypothécaire en garantie d'une seule et même créance. ... on se trouve donc en présence ici d'un gage collectif au sens de l'art. 798 al. 1 CC."); DÜRR, Art. 798 N 67; SCHMID-TSCHIRREN (2016), Art. 798 N 2; SCHMID-TSCHIRREN (2015), Art. 798 N 2; LEEMANN, Art. 798 N 6 vd.; SCHMID/HÜRLIMANN-KAUP, N 1519; GÜRSOY/EREN/CANSEL, s. 1036.

52 KURŞAT, s. 413; GÜRSOY/EREN/CANSEL, s. 1040.

${ }^{53}$ FASEL, Art. 798 N 6; SCHMID-TSCHIRREN (2015), Art. 798 N 12; HELVACI, s. 213. krş. ÖZER, s. 64.

${ }^{54}$ SCHMID-TSCHIRREN (2015), Art. 798 N 12; LEEMANN, Art. 798 N 39.

${ }^{55}$ SCHMID-TSCHIRREN (2016), Art. 798 N 2; SCHMID-TSCHIRREN (2015), Art. 798 N 2; LEEMANN, Art. 798 N 6 vd.; SCHMID/HÜRLIMANN-KAUP, N 1519; DÜRR, Art. 798 N 67; GÜRSOY, s. 8; ACAR, Rehin, N 95; ÇETİNER, s. 203.

${ }^{56}$ FASEL, Art. 798 N 6; SCHMID-TSCHIRREN (2015), Art. 798 N 12; HELVACI, s. 213. krş. ÖZER, s. 64.

${ }^{57}$ SCHMID-TSCHIRREN (2015), Art. 798 N 12; LEEMANN, Art. 798 N 39.
} 
TBK m. 189/I hükmü uyarınca kendiliğinden alacağı devralana geçecektir. TMK m. 891 hükmü, alacağın fer'isi olan rehin hakkının alacağın devredildiği yeni alacaklıya intikali açısından tapu kütüğüne tescilin şart olmadığını düzenlemiştir ${ }^{58}$. Bu durum, rehin hukukuna hâkim kamuya açıklık ilkesinin istisnalarından birini teşkil eder ${ }^{59}$.

\section{Toplu Rehin Sözleşmesi}

Toplu rehin sözleşmesinin tarafları, TMK m. 855/I hükmünden anlaşılabilmektedir. Borçlu tarafta; rehinle yüklenecek taşınmazların, maliki ya da müteselsil borçlu malikleri yer alır. Alacağı temin edilecek kişi ise toplu rehin sözleşmesinin alacaklı tarafını oluşturur. Toplu rehin sözleşmesi, TMK m. 856/II hükmü uyarınca resmî şekilde yapılmalıdır.

Toplu rehin; birlikte rehnin istisnaî türünü teşkil ettiği için, tarafların toplu rehin tesis etmek istediklerinin açıkça anlaşılması gerekir ${ }^{60}$. Bu sebeple toplu rehnin şartları mevcut olsa dahi, tarafların resmî yazılı şekilde yapacağ 1 toplu rehin sözleşmesi ile bu husus açıkça kararlaştırılmadıkça taşınmazlar üzerinde toplu rehin kurulamaz ${ }^{61}$. Böyle bir anlaşmanın mevcut olmamas1 hâlinde, TMK'de kural olarak öngörülen paylı rehin hükümleri uygulanır ${ }^{62}$.

TMK m. 851/I düzenlemesi uyarınca toplu rehin sözleşmesinde temin edilen alacağın miktarının belirli olması şart değildir. Bu bakımdan tarafların, anapara veya üst sınır ipoteği şeklinde teminatı belirleyebilmeleri mümkündür ${ }^{63}$.

\footnotetext{
${ }^{58}$ ÖZER, s. 63-64.

${ }^{59}$ ACAR, Rehin, N 70.

${ }^{60}$ YHGK, T. 27.11.2002, E. 2002/12-823, K. 2002/1020 (“Bu bakımdan rehinin toplu olduğu kuruluş sözleşmesinde belirtilmelidir.”); Yarg. 8. HD, T. 31.12.2013, E. 2013/21690, K. 2013/20428 ("Toplu rehin olgusu kuruluşs sözleşmesinde açıç̧a belirtilmelidir."); FASEL, Art. 798 N 5; SCHMID-TSCHIRREN (2016), Art. 798 N 9; SCHMID-TSCHIRREN (2015), Art. 798 N 10; LEEMANN, Art. 798 N 28; HRUBESCH-MILLAUER/GRAHAMSIEGENTHALER/ROBERTO, N 09.70; AKIPEK/AKINTÜRK/ATEŞ, s. 762; HELVACI, s. 218; KÖPRÜLÜ/KANETİ, s. 292; ÇETINER, s. 204; ACAR, Belirlilik, s. 253; ACAR, Rehin, N 95.

${ }^{61}$ KURŞAT, s. 406. krş. AYDIN ÜNVER, s. 95 vd.

${ }^{62}$ YHGK, T. 27.11.2002, E. 2002/12-823, K. 2002/1020 (“Kuruluşsözleşmesinde toplu rehin olgusunun açıkça belirtilmemiş olması, dolayısıyla da tarafların "toplu rehin" kurma yolunu seçmemişs olmaları halinde ikinci bir yol "aynı alacak için birden fazla taşınmazın rehin yükünün rehnedilecek taşınmazlar arasında paylaştırılıp, dağıtılması" dır."); Yarg. 8. HD, T. 31.12.2013, E. 2013/21690, K. 2013/20428 ("Açıkça belirtilmemesi ikinci bir yol olan, aynı alacak için birden fazla taşınmazın rehin yükünün, rehnedilecek taşınmazlar arasında paylaştırılıp dağıtılarak belirlenmesi gerektiği sonucunu doğurur.”).

${ }^{63}$ GÜRSOY, s. 9; KURŞAT, s. 409; ÇETINNER, s. 200.
} 
Toplu rehin sözleşmesinde önem arz eden başka bir husus, tarafların rehin türü konusunda anlaşmaları ve bütün taşınmazlar üzerinde aynı türden rehin kurmalarıdır. Bunun sebebi, toplu rehin sözleşmesi neticesinde tek bir rehin hakkının doğmasıdır. Şu hâlde taraflar her ne kadar toplu rehni; ipotek (Grundpfandverschreibung), ipotekli borç senedi (Schuldbrief) veya irat senedi (Gült) ile kurma konusunda serbestlerse de ${ }^{64}$ bütün taşınmazlar üzerinde aynı türden rehin kurmak zorundadırlar ${ }^{65}$. TMK m. 907/I çerçevesinde başkasının borcunu irat senedi ile temin etmek mümkün olmadığından, taşınmazların maliki farklı kişiler olduğu takdirde irat senedi ile toplu rehin kurulamaz ${ }^{66}$. Toplu rehin, ipotekli borç senedi veya irat senedi şeklinde tesis edilmişse TST m. 42/I hükmü gereğince sadece tek bir senet tanzim edilir. Rehnin tescil edileceği derece her taşınmazda farklılık arz edebilir ${ }^{67}$.

Toplu rehin, sözleşme ile baştan itibaren tesis edilebileceği gibi, aynı alacağa sonradan yeni teminatlar eklenmesi sebebiyle de ortaya çıkabilir. Aynı alacak varlığını sürdürmekle birlikte alacağın miktarı artırılır. Uygulamada özellikle kredi limitlerinin artırılması hâlinde alacağı temin etmek üzere toplu rehin söz konusu olabilmektedir ${ }^{68}$. Şüphesiz toplu rehnin uygulanabilmesi, toplu rehnin tüm şartlarının mevcut olmasına bağlıdır.

Öğretide, tarafların yaptıkları rehin sözleşmesinde hem toplu rehnin hem de paylı rehnin uygulanmasını öngörebilecekleri kabul edilmektedir ${ }^{69}$. $\mathrm{Bu}$ durumda, alacağın bir kısmı tüm taşınmazlar tarafından toplu rehin ile

\footnotetext{
${ }^{64}$ İsviçre hukukunda 11.12.2009 tarihli federal kanun ile irat senedine ilişkin hükümler, 01.01.2012 tarihi itibarıyla yürürlükten kaldırılmıș olduğu için İsviçre hukuku bakımından taşınmaz rehni ve doğal olarak toplu rehin, sadece ipotek veya ipotekli borç senedi şeklinde kurulabilir. Bu doğrultuda bkz. TUOR/SCHNYDER/SCHMID/JUNGO, § $112 \mathrm{~N} 24 \mathrm{dn}$. 29; FASEL, Art. 798 N 5; SCHMID-TSCHIRREN (2016), Art. 798 N 10; SCHMIDTSCHIRREN (2015), Art. 798 N 9; SCHMID/HÜRLIMANN-KAUP, N 1854.

${ }^{65}$ YHGK, T. 27.11.2002, E. 2002/12-823, K. 2002/1020 (“Toplu ... rehinin türü de rehin kapsamındaki tüm taşınmazlar için aynı olmalıdır.”); LEEMANN, Art. 798 N 9-10; SCHMID-TSCHIRREN (2016), Art. 798 N 10; SCHMID-TSCHIRREN (2015), Art. 798 N 9; SAYMEN/ELBİR, s. 584-585; ÇETINER, s. 201; KURŞAT, s. 411; KÖPRÜLÜ/KANETI, s. 293; GÜRSOY/EREN/CANSEL, s. 1037; ACAR, Belirlilik, s. 256; ÖZER, s. 38.

${ }^{66}$ ÖZER, s. 38-39.

${ }^{67}$ MARCHAND, Art. 798 N 9; LEEMANN, Art. 798 N 11; SCHMID-TSCHIRREN (2015), Art. 798 N 3; DÜRR, Art. 798 N 78; SCHMID-TSCHIRREN (2015), Art. 798 N 9; GÜRSOY/ EREN/CANSEL, s. 1037; WIELAND, Art. 798 N 2; SAYMEN/ELBİR, s. 585; ÇETINER, s. 201.

${ }^{68}$ KURŞAT, s. 409-410.

${ }^{69}$ DÜRR, Art. 798 N 171 vd.; LEEMANN, Art. 798 N 54; KUNTALP, s. 275 vd.
} 
temin edilirken geri kalanı paylı rehin ile temin edilmektedir ${ }^{70}$. Toplu rehnin kurulabilmesi için TMK m. 855/I hükmünde aranılan şartların bulunmas1 gerektiği için özellikle taşınmazların tamamı açısından toplu rehnin şartları sağlanmadığı takdirde böyle bir uygulama tercih edilebilir ${ }^{71}$.

\section{E. Tescil Zorunluluğu}

Toplu rehin TMK m. 856/I hükmü uyarınca, tıpkı diğer aynî haklar gibi, kural olarak tapu siciline tescil ile kurulur. Tescil işlemi, her bir taşınmaz açısından ayrı ayrı gerçekleştirilmelidir ${ }^{72}$. TST m. 32 hükmü, toplu rehinde tescilin nasıl yapılacağını düzenlemiştir. Buna göre, rehin ile yüklenen her bir taşınmazın sayfasında rehinler sütununa alacak miktarının tamamı (Pfandsumme) yazılır ve düşünceler sütununa taşınmazın, hangi taşınmazlarla birlikte rehnedildiği belirtilerek taşınmazlar arasında hukukî irtibat sağlanır ${ }^{73}$. Özetle toplu rehinde tüm taşınmazlar, aynı rehin miktarı ile yüklenirler ve tüm rehin miktarı ile sorumlu olurlar ${ }^{74}$. Müteselsil borçluluk söz konusuysa TST m. 32/I/b hükmü uyarınca bunun da düşünceler sütununda belirtilmesi gerekir.

TMK m. 1000/IV ve TST m. 28/VI hükümleri aynı malike ait olan birden çok taşınmazın, malikin istemi üzerine tapu kütüğünde ortak bir sayfaya (Kollektivblatt, feuillet collectif) kaydedilmesine imkân tanımaktadır ${ }^{75}$. Bu doğrultuda taşınmazların maliki, taşınmazlarını ortak bir

${ }^{70}$ KUNTALP, s. 276.

${ }^{71}$ DÜRR, Art. 798 N 173; KUNTALP, s. 276-277.

${ }^{72}$ GÜRSOY, s. 9.

${ }^{73}$ TUOR/SCHNYDER/SCHMID/JUNGO, § 112 N 32; SCHMID-TSCHIRREN (2015), Art. 798 N 5; DÜRR, Art. 798 N 75; AKİPEK/AKINTÜRK/ATEŞ, s. 762; SARI, s. 1005; KÖPRÜLÜ/KANETİ, s. 292; ÇETINER, s. 201. krş. GÜRSOY, s. 9-10; KURŞAT, s. 406. İnşaatçı ipoteğinin amacı, inşanın yapıldığı taşınmaz üzerinde ipotek kurulması olduğu için çok sayıda bağımsız bölüm üzerinde toplu rehin olarak inşaatçı ipoteğinin kesin tescilinin caiz olmadığı; ancak geçici tescil şerhinin yapılabileceği yönünde bkz. SCHMID-TSCHIRREN (2015), Art. 798 N 6a; SCHUMACHER, N 594, 839.

${ }^{74}$ MARCHAND, Art. 798 N 1, 7; TUOR/SCHNYDER/SCHMID/JUNGO, § 112 N 32; SCHMID-TSCHIRREN (2015), Art. 798 N 7, 8; SCHMID-TSCHIRREN (2016), Art. 798 N 2, 11; LEEMANN, Art. 798 N 1, 20; FASEL, Art. 798 N 5; ACAR, Belirlilik, s. 242, 256257; TEKINAY, s. 74.

${ }^{75}$ Anılan taşınmazların aynı veya farklı tapu sicili bölgesinde bulunması bakımından TMK'de bir ayrım yapılmamıştır. Farklı tapu sicili bölgesinde bulunan taşınmazlar açısından ise nasıl bir usûl izleneceği belirsizdir. eTST m. 36 hükmü, üzerinde rehin kurulacak taşınmazlardan herhangi birinin bulunduğu tapu siciline müracaat edilebileceğini öngörmesine rağmen TST'de bu yönde bir düzenleme bulunmamaktadır. Bu husustaki açıklamalar için bkz. LEEMANN, Art. 798 N 32 vd.; WIELAND, Art. 798 N 3; GÜRSOY/EREN/CANSEL, s. 1038; SAYMEN/ELBİR, s. 583-584. Mülga hükümde öngörülmüş uygulamanın sürdürülmesi gerektiği yönünde bkz. ÖZER, s. 46-47. 
sayfaya kaydettirmişse, o zaman toplu rehin de sadece ortak sayfaya yapılacak tescille kurulabilir ${ }^{76}$. TST m. 28/VI hükmü, ortak sayfaya kaydedilmiş taşınmazların asıl sayfaları üzerinde, herhangi bir işlem yapılamayacağını açıkça düzenlemiştir. Bu sebeple ortak sayfaya kaydedilmiş olan taşınmaz üzerinde toplu rehin; sadece ortak sayfaya yapılacak tescille kurulabilir.

Ortak sayfaya toplu rehnin kaydedilebilmesi için ortak sayfadaki tüm taşınmazların rehnedilmesi gerekir; zira toplu rehin ortak sayfada kayıtlı bulunan taşınmazların tamamını kapsamıyorsa TST m. 32/I/ç uyarınca ortak sayfaya tescil yapılamaz ${ }^{77}$. Bu sebeple ortak sayfada yer alan bir veya birkaç taşınmaz toplu rehin dışında tutulmak isteniyorsa, önce taşınmazın ortak sayfadan çıkarılması gerekir ${ }^{78}$.

Öğretide, toplu rehnin tescilinde alınacak harç miktarının paylı rehnin harç miktarını geçmemesi gerektiği haklı olarak ifade edilmektedir ${ }^{79}$. Her bir taşınmaz, alacak miktarının tamamıyla yükleneceğinden, her bir taşınmaz için alacak miktarı üzerinden harç hesaplanması mükerrerliğe yol açar. Tek bir rehin hakkı kurulduğu için tapu harcına esas teşkil edecek matrah, sadece alacak miktarıdır ${ }^{80}$.

TMK m. 855/I hükmündeki şartların bulunmamasına rağmen toplu rehin tescil edilmişse yolsuz tescilden bahsedilir ${ }^{81}$. Toplu rehne konu her taşınmazın maliki TMK m. 1025 uyarınca yolsuz tescilin düzeltilmesi davası açabilir ${ }^{82}$. Dava, rehin alacaklısına yöneltilir ve paylı rehin uyarınca toplam rehin yükünün, rehnin konusu taşınmazlara dağıtılması talep edilirr ${ }^{83}$. Eğer toplu rehnin tesciline ilişkin yanlışlık tapu memurunun hatasından kaynaklanmışsa

\footnotetext{
${ }^{76}$ MARCHAND, Art. $798 \mathrm{~N}$ 10; TUOR/SCHNYDER/SCHMID/JUNGO, § $112 \mathrm{~N} 33$; SCHMID-TSCHIRREN (2016), Art. 798 N 6; SCHMID-TSCHIRREN (2015), Art. 798 N 5; DÜRR, Art. 798 N 74; LEEMANN, Art. 798 N 30-31; GÜRSOY/EREN/CANSEL, s. 1039; GÖKTÜRK, s. 1038; SAYMEN/ELBİR, s. 583; KURŞAT, s. 407; OĞUZMAN/SELIÇĊI/ OKTAY-ÖZDEMIIR, N 3213 dn. 37; KÖPRÜLÜ/KANETI, s. 292; HELVACI, s. 219 dn. 32; ÇETINER, s. 201; ÖZER, s. 46.

${ }^{77}$ SCHMID-TSCHIRREN (2015), Art. 798 N 5.

${ }^{78}$ OĞUZMAN/SELIÇĊ/OKTAY-ÖZDEMIR, N 3219; ÇETINER, s. 201.

${ }^{79}$ LEEMANN, Art. 798 N 37; GÜRSOY, s. 18; ÖZER, s. 47-48.

80 KURŞAT, s. 408. Farklı tapu sicilindeki taşınmazlardan biri için harç tahsili yapılmışsa, diğer tapu müdürlüklerinden ayrı bir harç talebinde bulunulmayacağı yönünde bkz. ÖZER, s. 48.

${ }^{81}$ KUNTALP, s. 277; AYDIN ÜNVER, s. 93.

82 SCHMID-TSCHIRREN (2015), Art. 798 N 21; GÜRSOY, s. 11; DAVRAN, s. 27; KUNTALP, s. 277; AYDIN ÜNVER, s. 93. Tahvil ile ayakta tutma açısından bkz. BENGISU, s. 1885.

${ }^{83}$ SCHMID-TSCHIRREN (2015), Art. 798 N 21.
} 
o zaman TMK m. 1027 çerçevesinde tapu memurundan düzeltme talebinde bulunulabilir veya mahkemeden düzeltmeye karar vermesi talep edilebilir ${ }^{84}$.

\section{Toplu Rehnin Hüküm ve Sonuçları}

Toplu rehinde, üzerinde rehin kurulan taşınmaz sayısı kadar mı, yoksa sadece tek bir rehin hakkının mı doğduğu öğretide tartışma konusudur. Öğretide savunulan ağırlıklı görüş, toplu rehin hâlinde sadece tek bir rehin hakkının mevcut olduğu yönündedir ${ }^{85}$. Aksi görüş ise toplu rehin hâlinde taşınmaz sayısı kadar rehin hakkı doğduğunu savunmaktadır ${ }^{86}$. Kanaatimizce toplu rehin söz konusuysa sadece tek bir rehin hakkı kurulur.

Toplu rehinde rehinle yüklü taşınmazlardan biri veya birkaç tanesi, teminat altına alınan alacağın tamamını karşılamaya yeterse rehin yükü diğer taşınmazlar üzerinde maddî olarak sona erer ${ }^{87}$. Ayrıca toplu rehnin, tüm taşınmazlar üzerinde aynı rehin türünde kurulması gerekliliği de tek bir rehin

${ }^{84}$ DÜRR, Art. 798 N 181; SCHMID-TSCHIRREN (2015), Art. 798 N 21; LEEMANN, Art. 798 N 57-58.

${ }^{85}$ SCHMID-TSCHIRREN (2016), Art. 798 N 1-2; SCHMID-TSCHIRREN (2015), Art. 798 N 2; LEEMANN, Art. 798 N 6 vd.; SCHMID/HÜRLIMANN-KAUP, N 1519; FASEL, Art. 798 N 1; DÜRR, Art. 798 N 67 vd., 73; HELVACI, s. 213; AKİPEK/AKINTÜRK/ATEŞ, s. 762; WIELAND, Art. 798 N 2; SİRMEN, s. 587; SARI, s. 1005; KURŞAT, s. 410-411; ÇETINER, s. 201; ÖZER, s. 26-27; DAVRAN, s. 27; GÜRSOY, s. 8; KUNTALP, s. 271; GÜRSOY/EREN/CANSEL, s. 1036; KÖPRÜLÜ/KANETİ, s. 291.

${ }^{86}$ Yarg. 8. HD, T. 31.12.2013, E. 2013/21690, K. 2013/20428 (“... birden fazla taşınmaz üzerinde kurulu rehinler arasında hukuki bağlllık vardır ...”); OĞUZMAN/SELIÇİ/OKTAYÖZDEMIR, N 3224; ACAR, Rehin, N 97; ACAR, Belirlilik, s. 257 vd.

${ }^{87}$ YHGK, T. 27.11.2002, E. 2002/12-823, K. 2002/1020 (“Böylece rehinli taşınmazlardan birisinin paraya çevrilmesi halinde rehinli alacaklı alacağını tahsil etmişse artık diğer taşıınmaz üzerindeki rehinin konusu kalmayacak ve sona erecektir."); Yarg. 8. HD, T. 31.12.2013, E. 2013/21690, K. 2013/20428 ("Böylece rehinli taşınmazlardan birisinin paraya çevrilmesi halinde rehinli alacaklı alacă̆ını tahsil etmişse artık diğer taşınmaz üzerindeki rehnin konusu kalmayacak ve sona erecektir.”); Yarg. 12. HD, T. 23.11.2001, E. 2001/17448, K. 2001/19796 ("Bu gibi halde alacakl, rehinli taşınmazın birisinin paraya çevrilmesi ile alacă̆ın elde ederse diğer taşınmazlar üzerindeki rehin sona erer."); SCHMID-TSCHIRREN (2015), Art. 798 N 16; LEEMANN, Art. 798 N 6-7; OĞUZMAN/ SELIÇİ/OKTAY-ÖZDEMIR, N 3225; GÜRSOY/EREN/CANSEL, s. 1037; DAVRAN, s. 27; HELVACI, s. 222; KÖPRÜLÜ/KANETİ, s. 291; KUNTALP, s. 272; ÖZER, s. 26; GÜRSOY, s. 8-9; SİRMEN, s. 587; AYDIN ÜNVER, s. 91. Nitekim paylı rehin ile toplu rehnin temel fark1, toplu rehinde alacak elde edilince diğer taşınmazlar üzerindeki rehnin de sona ermesidir. Bu doğrultuda bkz. YHGK, T. 27.11.2002, E. 2002/12-823, K. 2002/1020: "Her iki rehin biçiminin arasındaki en temel fark da burada ortaya çıkmaktadır." Rehnin diğer taşınmazlar üzerinde maddî olarak sona ermesi hâlinde malik, TMK m. 883 uyarınca alacaklıdan rehnin terkin edilmesine rıza göstermesini talep edebilir. Bu doğrultuda bkz. SCHMID-TSCHIRREN (2015), Art. 798 N 15. 
hakkının kurulduğu fikrini desteklemektedir ${ }^{88}$.

Toplu rehin hakkının sahibi, TMK m. 1014 düzenlemesi çerçevesinde tüm maliklerin ya da müteselsil borçluların onayını alarak bazı taşınmazları rehnin kapsamından çıkartarak sorumluluktan kurtarabilir ${ }^{89}$. Keza rehin hakkı sahibi, yüklü taşınmazın maliki ile anlaşarak rehin hakkından sonra gelen bir sınırlı aynî hakkı rehin hakkının önüne geçirebilir; böyle bir sıra değişikliği için de diğer müteselsil sorumlu maliklerin rızası gerekir ${ }^{90}$. Tüm taşınmazlar aynı rehin yüküyle yüklendiği için sonradan sadece taşınmazların birinde veya bazılarında yük değişikliği yapılamaz ${ }^{91}$.

Bununla birlikte rehin hakk1 sahibi; toplu rehin hakkını, rehin yükünü -elbette rehinle yüklü taşınmazların malikleri ile anlaşarak- arzu ettiği gibi taşınmazlara dağıtarak ve bu durumu tapu sicilinde rehin sütununa tescil ettirerek münferit rehin haklarına çevirebilirr ${ }^{92}$ Böylece hak sahibi, artık alacağın her bir kısmından sadece tek taşınmaz sorumlu olacağı için rehin hakkından kısmen feragat etmiş olur ${ }^{93}$. Keza alacaklı, her bir rehin borçlusu ile anlaşarak ve rehin yüklerini taşınmazlara dağıtarak toplu rehni paylı rehne de çevirebiliri ${ }^{94}$.

\section{Toplu Rehnin Paraya Çevrilmesi}

Toplu rehinde her bir taşınmaz tüm meblağ ile sorumlu olduğu için ${ }^{95}$ alacaklının, TMK m. 873/III hükmüne göre toplu rehinle yüklü taşınmazların tamamının paraya çevrilmesini talep etmesi gerekir ${ }^{96}$. Alacaklının tüm

\footnotetext{
${ }^{88}$ MARCHAND, Art. 798 N 9; DÜRR, Art. 798 N 76; GÜRSOY/EREN/CANSEL, s. 1037; SAYMEN/ELBİR, s. 584-585; WIELAND, Art. 798 N 2; KUNTALP, s. 272; ÇETİNER, s. 201.

${ }^{89}$ FASEL, Art. 798 N 6; SCHMID-TSCHIRREN (2015), Art. 798 N 12; LEEMANN, Art. 798 N 39 vd.; ÇETINER, s. 203-204; KURŞAT, s. 414.

${ }^{90}$ SCHMID-TSCHIRREN (2015), Art. 798 N 12; GÜRSOY/EREN/CANSEL, s. 1040; KUNTALP, s. 272; KURŞAT, s. 414.

${ }^{91}$ SCHMID-TSCHIRREN (2015), Art. 798 N 13; KURŞAT, s. 414; GÜRSOY/EREN/ CANSEL, s. 1040. Farklı görüş için bkz. LEEMANN, Art. 798 N 41 vd.

92 SCHMID-TSCHIRREN (2015), Art. 798 N 14; GÜRSOY/EREN/CANSEL, s. 1040; KURŞAT, s. 414.

${ }^{93}$ SCHMID-TSCHIRREN (2015), Art. 798 N 14; LEEMANN, Art. 798 N 44-45.

${ }^{94}$ ÇETINER, s. 204.

${ }^{95}$ FASEL, Art. 798 N 5; SCHMID-TSCHIRREN (2016), Art. 798 N 2, 11; SCHMIDTSCHIRREN (2015), Art. 798 N 7; LEEMANN, Art. 798 N 1.

${ }^{96}$ BGE 138 III 186; BGE 136 III 34 E. 2 (“... on se trouve donc en présence ici d'un gage collectif au sens de l'art. 798 al. 1 CC. En pareil cas, le créancier doit poursuivre simultanément la réalisation de tous les immeubles ..."); TUOR/SCHNYDER/SCHMID/JUNGO, § $112 \mathrm{~N}$
} 
taşınmazların paraya çevrilmesini talep etme mecburiyeti, alacaklının rehinle yüklü taşınmaz maliklerinden bazıları ile anlaşıp diğerlerinin zararına olacak şekilde paraya çevrilecek taşınmazları seçme tehlikesine karşı öngörülmüştür ${ }^{97}$. Bununla birlikte icra dairesi; alacağı karşılayabilecek, yani sadece gerekli olan taşınmazların satışına karar veriri" ${ }^{98}$ Bu bakımdan toplu rehnin konusu olan tüm taşınmazların paraya çevrilmesi zorunlu değildir99. Ancak icra dairesinin toplu rehin konusu taşınmazlardan hangilerinin satışına karar vereceğine dair herhangi bir k1stas öngörülmemiştir ${ }^{100}$.

Öğretide taşınmazların kime ait olduğundan hareketle, taşınmazların paraya çevrilmesine ilişkin çeşitli öneriler yapılmaktadır: Tüm taşınmazların maliki aynı kişi ise icra dairesi, malike asgarî zarar verecek şekilde paraya çevrilecek taşınmazları belirler ${ }^{101}$. Taşınmazların malikleri farklıysa ve taşınmazlardan en az bir tanesi borçluya aitse öncelikle borçlunun taşınmazının paraya çevrilmesi gerektiği, ancak rehinli alacağın tamamının karşılanamaması hâlinde borçlunun borcunu temin etmek üzere taşınmazlarını rehneden üçüncü kişilerin taşınmazlarının paraya çevrileceği savunulmaktadır ${ }^{102}$. Öte yandan bu durumda taşınmazlar farklı kişilere ait olduğu için taşınmazların

34; LEEMANN, Art. 798 N 16; HRUBESCH-MILLAUER/ GRAHAM-SIEGENTHALER/ ROBERTO, N 09.71; SCHMID-TSCHIRREN (2015), Art. 798 N 17; AKİPEK/AKINTÜRK/ ATEŞ, s. 762-763; TEKINAY, s. 75; WIELAND, Art. 798 N 1; DAVRAN, s. 29; SARI, s. 1006; ACAR, Belirlilik, s. 261; KURŞAT, s. 424; HELVACI, s. 220; GÖKTÜRK, s. 1039; KUNTALP, s. 289; SİRMEN, s. 587; AYDIN ÜNVER, s. 87. Anılan hükmün emredici olduğu yönünde bkz. BGE 100 III 50 E. 2; GÜRSOY, s. 12; HRUBESCH-MILLAUER/ GRAHAM-SIEGENTHALER/ROBERTO, N 09.71.

${ }^{97}$ YHGK, T. 27.11.2002, E. 2002/12-823, K. 2002/1020; Yarg. 8. HD, T. 31.12.2013, E. 2013/21690, K. 2013/20428; LEEMANN, Art. 798 N 16.

${ }^{98}$ Yarg. 12. HD, T. 23.11.2001, E. 2001/17448, K. 2001/19796 (“... hangi taşınmazın önce satılacağı konusunda seçimlik hak icra müdürüne aittir."); HRUBESCH-MILLAUER/ GRAHAM-SIEGENTHALER/ROBERTO, N 09.71; TUOR/SCHNYDER/SCHMID/ JUNGO, § 112 N 34; KÖPRÜLÜ/KANETİ, s. 294; GÜRSOY/EREN/ CANSEL, s. 1040; TEKINAY, s. 75; SARI, s. 1006; ACAR, Belirlilik, s. 248-249; GÖKTÜRK, s. 1039; AKIPEK/AKINTÜRK/ATEŞ, s. 763; HELVACI, s. 220-221; SİRMEN, s. 587; KURŞAT, s. 424; KUNTALP, s. 289-290; AYDIN ÜNVER, s. 87. Takipte yetkili icra dairesinin İIKK m. 148 uyarınca belirleneceği; buna göre İIK $\mathrm{m}$. 50 çerçevesinde genel yetkili icra dairesine veya rehinli taşınmazların bulunduğu yer icra dairesine başvurulabileceği yönünde bkz. GÜRSOY, s. 22; KURŞAT, s. 425.

99 TUOR/SCHNYDER/SCHMID/JUNGO, § 112 N 34.

100 KURŞAT, s. 424-425; GÜRSOY, s. 22-24.

${ }^{101}$ DAVRAN, s. 29; HELVACI, s. 223 vd.; KÖPRÜLÜ/KANETİ, s. 294; GÖKTÜRK, s. 1039; KUNTALP, s. 290; KURŞAT, s. 424-425; GÜRSOY, s. 23.

102 GÜRSOY, s. 23; GÖKTÜRK, s. 1040; KÖPRÜLÜ/KANETİ, s. 294; HELVACI, s. 225-226. 
tamamının paraya çevrilmesi gerektiğini belirtenler de vardır ${ }^{103}$. Örneğin; toplu rehnin konusunu oluşturan bazı taşınmazlar üzerinde başka rehin haklarının bulunması hâlinde bunların alacaklılarının zarara uğrayabileceği, bu nedenle de tüm taşınmazların paraya çevrilmesinin daha isabetli olacağı belirtilmektedir ${ }^{104}$.

\section{Rehinli Taşınmazın Sonradan Birden Fazla Taşınmazla Teminat Altına Girmesi}

Rehin kurulurken toplu rehin kararlaştırılabileceği gibi, rehinle yüklenmiş bir taşınmazın sonradan bölünmesi veya kat mülkiyetine çevrilmesi hâllerinde de toplu rehin ortaya çıkabilir ${ }^{105}$. Burada söz konusu olan bölünme; TMK m. 868 uyarınca taşınmazın küçük bir parçasının ayrılması değil, TMK m. 889 hükmü uyarınca taşınmazın bölünmesidir. Bu bakımdan taşınmazın bölünerek fiilen bağımsız taşınmazlar hâline gelmesi ve tapu siciline ayrı ayrı kaydedilmesi gereklidir ${ }^{106}$.

Taşınmazın bölünmesi hâlinde TMK m. 889/I, rehin yükünün taşınmazlara değerleri oranında paylaştııılmasını, yani paylı rehin kurulmasını öngörmüştür. Eğer taraflar arasında taşınmazlar üzerindeki rehin yükü paylaşımına dair bir anlaşma bulunmuyorsa, tapu müdürü dağıtımı re'sen yapar. Rehinli taşınmazın bölünmesi sonucunda toplu rehnin söz konusu olabilmesi toplu rehnin şartlarının sağlanmasına bağlıdır ${ }^{107}$. Bu bakımdan tek bir malike ait olan rehinle yüklü taşınmaz, TMK m. 889 uyarınca bölünürse ve tüm yeni taşınmazlar da aynı malike aitse veya malikler müteselsil borçluysa toplu rehin söz konusu olur ${ }^{108}$. Şartları oluşmamasına rağmen toplu rehnin tescili, yolsuz rehin teşkil eder ve TMK m. 1023 hükmünün uygulanabilmesine imkân sağlar ${ }^{109}$. KMK m. 5/V hükmü de tıpkı TMK m. 889/I hükmü gibi paylı rehnin kurulmasını öngörmüştür.

TMK m. 889/II hükmü uyarınca, yapılan rehin yükü dağıtımını kabul etmeyen alacaklı, alacağın bir yıl içinde ödenmesini talep edebilir. Alacaklı; bu tarz bir yazılı bildirimi, dağıtımın kesinleşmesinin kendisine tebliğinden

\footnotetext{
${ }^{103}$ KUNTALP, s. 291; KURŞAT, s. 424-425; DAVRAN, s. 29; GÜRSOY, s. 23. krş. HELVACI, s. 225.

104 KUNTALP, s. 291; GÜRSOY, s. 23-24.

105 KURŞAT, s. 394.

${ }^{106}$ KURŞAT, s. 415; ACAR, Belirlilik, s. 222.

${ }^{107}$ GÜRSOY, s. 26; KURŞAT, s. 418.

${ }^{108}$ SCHMID-TSCHIRREN (2016), Art. 798 N 5; GÜRSOY, s. 16-17.

${ }^{109}$ GÜRSOY, s. 17; ÖZER, s. 55.
} 
başlayarak bir ay içinde yapmalıdır. Yazılı bildirimin yapılmasından bir yıl sonra borç muaccel hâle gelir. Rehinli alacağın vadesi bir yıldan sonra dolacak olsa bile alacaklının yapacağı bildirim ile alacak bir yılın sonunda muacceliyet kazanir ${ }^{110}$.

\section{Rehinli Taşınmazlardan Birinin veya Birkaçının Devri}

TMK m. 888/I hükmü, taraflarca aksi kararlaştırılmadıkça rehinle yüklü taşınmazın devrinin, borçlunun sorumluluğunda ve teminatta bir değişikliğe yol açmayacağını düzenlemiştir. Üzerinde toplu rehin tesis edilmiş taşınmazların tamamının bir üçüncü kişiye veya bu taşınmazların bir kısmının aynı borçtan müteselsil borçlu kişiye devredilmesi hâllerinde toplu rehin için aranan şartlar varlığını sürdüreceğinden, taşınmazlar üzerindeki toplu rehin de devam eder ${ }^{111}$.

Buna karşı1ık TMK m. 855/I hükmünde öngörülen toplu rehin şartlarını taşımayan bir devir gerçekleşirse taşınmazlar üzerindeki toplu rehnin muhafaza edilebilmesi mümkün olmaz ${ }^{112}$. Bu durumda, TMK m. 889/I hükmü uygulama alanı bulur ve taraflar arasında aksine bir anlaşma yoksa rehin yükü, taşınmazların değeri oranında tapu idaresince re'sen paylaştırılır ${ }^{113}$.

Eğer toplu rehinle yüklü taşınmazlardan biri devredilirse ve yeni malik borçtan müteselsil sorumlu değilse TMK m. 889 hükmüne göre rehin yükünün dağıtılması zorunluluk arz eder. Eğer taraflar aralarında anlaşamazlarsa o zaman tapu memuru re'sen rehin yükünü dağıtır. Rehin alacaklısı, eski malik ile yeni malikin yaptığı rehin anlaşmasını kabul etmek zorunda değildir. Yapılan dağıtımından memnun kalmayan alacaklı, TMK m. 889/II uyarınca bir aylık süre içerisinde yapacağı bildirimle alacak hakkının bir yıl içerisinde ödenmesini talep edebilir ${ }^{114}$. Alacaklının talebi üzerine rehin yükü dağılmış olmaz ve toplu rehin devam eder ${ }^{115}$.

\footnotetext{
${ }^{110}$ ÖZER, s. 57.

${ }^{111}$ ÖZER, s. 71.

112 ÖZER, s. 71; ACAR, Belirlilik, s. 254-255; KURŞAT, s. 415.

113 ACAR, Belirlilik, s. 254-255; KUNTALP, s. 280; KURŞAT, s. 415; ÖZER, s. 71.

${ }^{114}$ BGE 114 II 328 E. 3c: "Diese haben sich nicht gegen ihren Willen jede Neuaufteilung gefallen zu lassen; es kann ihnen vielmehr einzig das in Art. 833 ZGB vorgezeichnete Ergebnis aufgezwungen werden, wobei gemäss Art. 833 Abs. 2 ZGB jeder Pfandgläubiger immerhin binnen Monatsfrist verlangen kann, dass seine Forderung innerhalb eines Jahres getilgt werde."

${ }^{115}$ KURŞAT, s. 415.
} 


\section{§ 2. PAYLI REHIN}

\section{Genel Olarak}

TMK m. 855/II-III ve TST m. 32/I/c çerçevesinde birden çok taşınmazın, her birinin sorumlu olduğu rehin yükü gösterilerek rehinle yüklenmesine "payl rehin" (Pfandhaftverteilung, Teilpfandrecht, Aufteilung der Pfandhaft, répartition du gage) denir"116. Öğretide bu minvalde "rehin yükünün taşınmazlar arasında paylaştırllması suretiyle kurulan rehin" ${ }^{117}$, "rehin yükünün birden fazla taşınmaz arasında paylaşılması"118, "güvence bölünerek oluşturulan rehin"119, "müşterek rehin"120, "kollektif olmayan rehin" 21 ve "teminatın bölünmesi" 122 kavramları da kullanılmaktadır. Toplu rehnin şartları mevcut değilse ya da mevcut olmasına rağmen taraflar toplu rehin yerine paylı rehin kurmak isterlerse her taşınmaza rehin yükü dağıtılarak paylı rehin kurulabilir ${ }^{123}$.

\section{Paylı Rehnin Konusu}

Toplu rehnin konusunu teşkil edebilecek taşınmazlar üzerinde paylı rehin de kurulabilir. Tekrardan kaçınmak adına, toplu rehnin konusuna ilişkin açıklamalarımıza burada sadece göndermede bulunmakla yetiniyoruz.

\section{Paylı Rehnin Şartları}

Toplu rehinden farklı olarak paylı rehinde, rehne konu taşınmazların aynı malike veya müteselsil borçlulara ait olması gerekli değildir ${ }^{124}$. Öte yandan yine toplu rehnin aksine, paylı rehnin kurulabilmesi için TMK m. 855/ II-III gereğince her bir taşınmazın sorumlu olacağı rehin yükünün belirlenmesi gerekir.

\footnotetext{
${ }^{116}$ DÜRR, Art. 798 N 10, 113 vd.

117 SIRMEN, s. 587.

${ }^{118}$ KÖPRÜLÜ/KANETİ, s. 294.

${ }^{119}$ ACAR, Rehin, N 92; ACAR, Belirlilik, s. 244.

${ }^{120}$ BENGISU, s. 1881.

${ }^{121}$ GÜRSOY, s. 19.

${ }^{122}$ KUNTALP, s. 267.

${ }^{123}$ SCHMID-TSCHIRREN (2016), Art. 798 N 12; SCHMID-TSCHIRREN (2015), Art. 798 N 18; DÜRR, Art. 798 N 116-119; MARCHAND, Art. 798 N 11; KUNTALP, s. 267; SCHMID/ HÜRLIMANN-KAUP, N 1520; HELVACI, s. 218, 227; SİRMEN, s. 587; ÇETINER, s. 205; AYDIN ÜNVER, s. 94, 98.

${ }^{124}$ ACAR, Belirlilik, s. 245.
} 


\section{A. Rehinle Yüklenecek Her Bir Taşınmazın Alacağın Ne Kadarını Temin Ettiğinin Belirtilmesi}

\section{Taraflarm Belirlemesi}

TMK m. 855/II hükmüne göre paylı rehin kurulurken tarafların, her bir taşınmazın, alacağın ne kadarlık kısmını temin ettiğini belirlemesi esastır $^{125}$. Taraflar, rehin sözleşmesinde rehin yükünün taşınmazlara nasıl paylaştırılacağını serbestçe kararlaştırabilirler ${ }^{126}$.

Taraflar rehin yükünün nasıl dağıtılacağını kararlaştırmamışlarsa TMK m. 855/III düzenlemesi çerçevesinde tapu idaresi rehin yükünü paylaştırır. Bununla birlikte öğretide; rehin sözleşmesi ile tescil talebinin birbirinin peşi sıra yapılması sebebiyle, tarafların paylı rehnin kurulması hususunda anlaşıp rehin yükünün dağılımında anlaşamamalarının çok mümkün olmadığı belirtilmektedir ${ }^{127}$.

\section{Tapu İdaresinin Belirlemesi}

Rehin sözleşmesinin tarafları arasında rehin yükünün nasıl paylaştırılacağına ilişkin bir anlaşma bulunmuyorsa tapu idaresi, TMK m. 855/III uyarınca rehin yükünü her bir taşınmaza değeri oranında re'sen dağıtır. Buna mukabil TST m. 32/I-c hükmü ise "Her bir taşınmaz veya payın ne miktar için rehnedildiği belirtilmezse istem reddedilir." düzenlemesini içermektedir. Anılan tüzük hükmünün, TMK m. 855/III hükmüne aykırı olduğu açıktır.

Tarafların anlaşamaması hâlinde tapu idaresinin rehin yükünün dağılımını nasıl gerçekleştireceği öğretide tartışmalıdır. TMK m. 855/III hükmünde tapu memurunun, rehin yükünü "taşınmazların her birine değeri oranında" dağıtacağı düzenlenmiştir. Şu hâlde, tapu memurunun dağıtımı yapabilmesi için paylı rehne konu taşınmazların değerlerini biliyor olması gerekir $^{128}$. Bu durumda tapu memuru, taşınmazların değerlerini gözeterek rehin yükünü, paylı rehne konu taşınmazlara dağıtır ${ }^{129}$. Şüphesiz taşınmazlarda

\footnotetext{
${ }^{125}$ ACAR, Belirlilik, s. 246; KUNTALP, s. 268-269; AYDIN ÜNVER, s. 89.

${ }^{126}$ MARCHAND, Art. 798 N 13; SCHMID-TSCHIRREN (2016), Art. 798 N 15; SCHMIDTSCHIRREN (2015), Art. 798 N 19; DÜRR, Art. 798 N 133; LEEMANN, Art. 798 N 52; OĞUZMAN/SELIÇĊI/OKTAY-ÖZDEMIR, N 3216; SİRMEN, s. 587; SARI, s. 1003 1004; KÖPRÜLÜ/KANETİ, s. 295; ÇETİNER, s. 206; GÜNEL, s. 248. İsviçre hukuku bakımından tarımsal taşınmazların yük sınırının dikkate alınması gerekliliği hakkında bkz. SCHMID-TSCHIRREN (2015), Art. 798 N 19; HRUBESCH-MILLAUER/GRAHAMSIEGENTHALER/ ROBERTO, N 09.72.

${ }^{127}$ KUNTALP, s. 270; KURŞAT, s. 401.

${ }^{128}$ SIRMEN, s. 588; ACAR, Belirlilik, s. 247.

${ }^{129}$ SCHMID-TSCHIRREN (2015), Art. 798 N 20; SCHMID/HÜRLIMANN-KAUP, N 1520.
} 
hâlihazırda mevcut olan rehin hakları bu aşamada dikkate alınarak taşınmazın değerinden indirilir ve taşınmazın geriye kalan değerine göre yük dağılımı gerçekleştirilir ${ }^{130}$.

Bununla birlikte taşınmazların değeri, tapu kayıtlarında bulunmayabilir veya bulunmakla beraber taşınmazların gerçek değerini yansıtmıyor olabilir ${ }^{131}$. $\mathrm{Bu}$ durumda tapu memurunun nasıl hareket edeceğine yönelik olarak öğretide dört görüş ileri sürülmüştür: İlk görüş; taraflar paylaşım konusunda bir belirlemede bulunmamış ve tapu memurunu da taşınmazların değeri hakkında bilgilendirmekten kaçınmışlarsa, tapu memurunun TST m. 32/I/c hükmü çerçevesinde paylı rehin tescil talebini reddedeceğini savunmaktadır ${ }^{132}$. Diğer bir görüş ise TST m. 32/I/c hükmünün son cümlesinin, TMK m. 855/III düzenlemesine aykırı olması sebebiyle uygulanamayacağını belirtmektedir ${ }^{133}$. Üçüncü görüş; tapu memurunun, taraflardan taşınmazların değerlerini kendisine bildirmelerini isteyebileceğini ve tarafların taşınmazların değerlerini bildirmemeleri hâlinde paylı rehin talebini reddedeceğini belirtmektedir ${ }^{134}$. $\mathrm{Bu}$ hususta ileri sürülen son görüş ise, tapu memurunun taşınmazların vergi değerlerine göre rehin yükünü paylaştırmayı taraflara önereceğini; ancak taraflarca bunun kabul görmemesi hâlinde rehin yükünün eTST m. 45/II hükmünde benimsendiği üzere hâkim tarafından dağıtılacağını ileri sürmektedir ${ }^{135}$.

\section{Mahkemenin Belirlemesi}

Taraflar yük dağılımında anlaşamazlarsa, tapu memurunun yaptığı paylaşımı taraflar kabul etmezlerse ya da tapu memuru taşınmazların değerlerinin eksik olması nedeniyle yük dağılımını gerçekleştiremezse son çare olarak her ilgili mahkemeden yük dağılımının tespit edilmesini talep edebilir ${ }^{136}$. Mahkeme, -varsa ön sıradaki rehinler ve taşınmaz yüklerinin

\footnotetext{
${ }^{130}$ SCHMID-TSCHIRREN (2015), Art. 798 N 20.

${ }^{131}$ KURŞAT, s. 401.

132 OĞUZMAN/SELIÇİ/OKTAY-ÖZDEMIR, N 3217; KÖPRÜLÜ/KANETİ， s. 295-296; SARI, s. 1004. krş. MARCHAND, Art. 798 N 14; DAVRAN, s. 27.

${ }^{133}$ SİRMEN, s. 587-588; HELVACI, s. 231 dn. 61; AYDIN ÜNVER, s. 99. eTST hükümleri çerçevesinde aynı doğrultuda bkz. KUNTALP, s. 269. Bu bakımdan krş. KÖPRÜLÜ/ KANETI, s. 295-296.

${ }^{134}$ SİRMEN, s. 588. krş. KÖPRÜLÜ/KANETİ, s. 295-296; KUNTALP, s. 270.

${ }^{135}$ KURŞAT, s. 401.

${ }^{136}$ SCHMID-TSCHIRREN (2015), Art. 798 N 19; SCHMID-TSCHIRREN (2016), Art. 798 N 16; GÜRSOY/EREN/CANSEL, s. 1034; ÖZER, s. 53; ACAR, Rehin, N 93; LEEMANN, Art. 798 N 55; DÜRR, Art. 798 N 151-152; ÇETINER, s. 207; WIELAND, Art. 798 N 5.
} 
değerini düşerek-her bir taşınmaza toplam rehin yükünün bir kısmını yükler ${ }^{137}$.

\section{B. Alacağın Aynı Olması}

TMK m. 855/II hükmüne göre paylı rehin, aynı alacak için kurulabilir. Bir başka ifadeyle paylı rehinde her taşınmaz, alacağın yalnızca belli bir miktarını teminat altına alır; ancak temin edilecek alacak tektir. Dolayısıyla, taşınmazlar üzerindeki rehin yükünün toplamı, teminat altına alınan alacağın miktarından fazla olmamalıdır ${ }^{138}$.

\section{Teminatın Bölünmesi}

Paylı rehinde temin edilen alacak hakkı bir tanedir; ancak güvence bölünmektedir ${ }^{139}$. Bu bakımdan toplu rehnin aksine paylı rehinde, her bir taşınmaz alacağın sadece bir kısmını temin eder. Bu sebeple alacaklı bakımından birden çok taşınmazın bağl1lı̆̆ , toplu rehindekine göre daha mühimdir ${ }^{140}$. Zira alacaklının tamamen tatmin olması, tüm taşınmazların paraya çevrilmesine ve her bir taşınmazın paraya çevrilmesinden rehin yükü kadar meblağın alacaklının eline geçmesine bağlıdır. Oysaki toplu rehinde taşınmazların sadece bazılarının paraya çevrilmesi ve elde edilen satış miktarının alacağı karşılaması mümkündür. Bu sebeple paylı rehnin, toplu rehne kıyasla rehin alacaklısının daha aleyhine olduğu açıktır ${ }^{141}$.

Paylı rehinde teminat bölündüğü için rehin alacaklısının, toplu rehnin aksine, alacağının tamamını devretme zorunluluğu yoktur. Aksine sadece arzu ettiği taşınmazlar üzerindeki rehin hakkının temin ettiği alacak miktarını devredebilir. Alacağın devri hâlinde alacağa bağlı olan rehin hakkı, TBK m. 189/I hükmü uyarınca kendiliğinden alacak hakkını devralana geçer. TMK m. 891 hükmüne göre rehin hakkının, alacağın devredildiği yeni alacaklıya intikali açısından tapu kütüğüne tescil şart değildir ${ }^{142}$. Bu bakımdan öğretide

\footnotetext{
${ }^{137}$ MARCHAND, Art. 798 N 16; SCHMID-TSCHIRREN (2016), Art. 798 N 16.

${ }^{138}$ KURŞAT, s. 399; HELVACI, s. 228; SİRMEN, s. 587.

139 YHGK, T. 27.11.2002, E. 2002/12-823, K. 2002/1020 (“Burada alacak tümlüğünü korur, ancak taşınmazlardan her biri alacağın yalnız belirli bir bölümü için sorumlu olur."); SCHMID/HÜRLIMANN-KAUP, N 1520; SCHMID-TSCHIRREN (2015), Art. 798 N 18; DÜRR, Art. 798 N 121; LEEMANN, Art. 798 N 48; OĞUZMAN/SELIÇ்̇/OKTAYÖZDEMIR, N 3216; SAYMEN/ELBİR, s. 582; KÖPRÜLÜ/KANETİ, s. 295; HELVACI, s. 228; ACAR, Rehin, N 92; ACAR, Belirlilik, s. 244; ÇETINER, s. 205; AYDIN ÜNVER, s. 88.

${ }^{140}$ DÜRR, Art. 798 N 124.

${ }^{141}$ GÜRSOY, s. 21.

142 ÖZER, s. 63-64. Bu durumun, rehin hukukuna hâkim kamuya açıklık ilkesinin istisnalarından birini teşkil etiği yönünde bkz. ACAR, Rehin, N 70.
} 
yüklü taşınmazların her birinin tapu kütüğü sayfasının düşünceler sütununa alacağın temlik edildiğinin kaydedilmesi gerektiği belirtilmektedir ${ }^{143}$.

\section{Paylı Rehin Sözleşmesi}

Paylı rehin sözleşmesi, taşınmaz maliki ya da malikleri ile rehin alacaklısı arasında yapılır. Paylı rehinde, taşınmazların aynı kişiye veya farklı kişilere ait olması mümkündür ${ }^{144}$. Keza farklı maliklerin müteselsil borçlu olması da gerekli değildir. TMK m. 856/II düzenlemesine göre paylı rehin sözleşmesi, resmî şekilde yapılır.

TMK m. 855 hükmü uyarınca birlikte rehin hâlinde paylı rehin kural olduğu için paylı rehnin açıkça kararlaştırılmasına gerek yoktur. Taraflar birlikte rehin kurmak istemekle birlikte toplu rehin kurmak istedikleri anlaşılamıyorsa paylı rehin söz konusu olur.

TMK m. 851/I uyarınca taraflar, ister anapara ister üst sınır ipoteği şeklinde paylı rehnin teminatını belirleyebilirler. Paylı rehinde birden çok rehin hakkı kurulduğu için farklı rehin türlerinde rehin hakkı kurulabilir, toplu rehindeki gibi rehin hakkının aynı türde kurulması zorunluluğu yoktur ${ }^{145}$. Rehin haklarının, her bir taşınmaz üzerinde farklı derecelerde kurulabilmesi mümkündür ${ }^{146}$.

\section{E. Tescil Zorunluluğu}

TMK m. 856/I hükmü uyarınca paylı rehnin tapu kütüğüne tescil edilmesi gerekir ${ }^{147}$. Tarafların üzerinde anlaştığı veya tapu idaresinin ya da mahkemenin tayin ettiği rehin yükleri, TST m. 32/I/c uyarınca her bir taşınmazın tapu kütüğü sayfasındaki rehin sütununa işlenir ${ }^{148}$.

TST m. 32/I/a-b uyarınca toplu rehinde düşünceler sütununda diğer taşınmazların belirtileceği açıkça düzenlenmiştir. Böyle bir düzenleme paylı rehin bakımından öngörülmemiş olsa da taşınmazların tamamının paraya çevrilmesi söz konusu olduğu için rehin konusu diğer taşınmazların, her bir taşınmazın tapu kütüğü sayfasında yer alan düşünceler sütununda belirtilmesi

\footnotetext{
143 ÖZER, s. 64.

${ }^{144}$ ACAR, Belirlilik, s. 245.

${ }^{145}$ SAYMEN/ELBİR, s. 583; GÜRSOY/EREN/CANSEL, s. 1035; ACAR, Belirlilik, s. 249. Aksi görüşte bkz. ÇETİNER, s. 205; DÜRR, Art. 798 N 122.

${ }^{146}$ DÜRR, Art. 798 N 130.

${ }^{147}$ Tapu memurunun, tescilin yolsuz olduğunu anladığı anda TMK m. 1007 çerçevesinde devletin sorumluluğuna gidilmesini engellemek için, TMK m. 1027 uyarınca tapu sicilini re'sen düzelteceği yönünde bkz. LEEMANN, Art. 798 N 59.

148 SARI, s. 1004; KURŞAT, s. 402; BENGİSU, s. 1881.
} 
isabetli olur ${ }^{149}$.

\section{Paylı Rehnin Hüküm ve Sonuçları}

Paylı rehinde temin edilen alacak hakkı bir tanedir; ancak güvence bölünmektedirr ${ }^{150}$. Güvencenin bölünmesi neticesinde, paylı rehinde her taşınmaz toplam rehin miktarının sadece belirli bir kısmından sorumlu olur ve birden fazla rehin hakkı kurulur ${ }^{151}$. Paylı rehin hâlinde, rehin yükü her bir taşınmaz üzerinde ayrı ayrı paylaştırıldığından taşınmaz adedi kadar rehin hakkı mevcuttur ${ }^{152}$. Paylı rehin her ne kadar aynı rehin sözleşmesi uyarınca tesis edilse de taşınmazlar üzerindeki rehin hakları birbirlerinden bağımsızdır ${ }^{153}$. Bu bağlamda her taşınmaz üzerinde rehin hakkının farklı türlerde kurulabilmesi de mümkündür ${ }^{154}$. Başka bir anlatımla, toplu rehinden farklı olarak, bir taşınmaz üzerinde ipotek ile rehin tesis edilirken bir başka taşınmaz üzerinde ipotekli borç senedi ile rehin kurulabilir.

Paylı rehinde sadecerehin yükübölünür, rehin alacaklısının bölünemeyen ve sadece tamamı üzerinde tasarruf edilebilen bir hakkı vardır ${ }^{155}$. Nitekim

149 KURŞAT, s. 402-403.

${ }^{150}$ Yarg. 12. HD, T. 23.11.2001, E. 2001/17448, K. 2001/19796 (“Bu tür ipotekler de alacak bölünmeyip bütünlüğ̈̈nü koruduğu halde rehin yükü taşınmazlara dağıtılmıştır.”); Yarg. 8. HD, T. 31.12.2013, E. 2013/21690, K. 2013/20428 (“Burada alacak tümlügünü korur, ancak taşınmazlardan her biri alacă̆ın yalnız belirli bir bölümü için sorumlu olur.”); SCHMID/ HÜRLIMANN-KAUP, N 1520; DÜRR, Art. 798 N 121; LEEMANN, Art. 798 N 48; SCHMID-TSCHIRREN (2015), Art. 798 N 18; OĞUZMAN/SELİÇİOKTAY-ÖZDEMİR, N 3216; SAYMEN/ELBİR, s. 582; KÖPRÜLÜ/KANETİ, s. 295; HELVACI, s. 228; ACAR, Rehin, N 92; ACAR, Belirlilik, s. 244; ÇETINER, s. 205; AYDIN ÜNVER, s. 88.

${ }^{151}$ MARCHAND, Art. 798 N 1, 12; TUOR/SCHNYDER/SCHMID/JUNGO, § 112 N 31; SCHMID-TSCHIRREN (2016), Art. 798 N 13; SCHMID-TSCHIRREN (2015), Art. 798 N 18; SCHMID/HÜRLIMANN-KAUP, N 1520; DÜRR, Art. 798 N 120-121; LEEMANN, Art. 798 N 48-50; KUNTALP, s. 268; DAVRAN, s. 26; SIRMEN, s. 587; HELVACI, s. 227228; ACAR, Rehin, N 94; ACAR, Belirlilik, s. 249; AYDIN ÜNVER, s. 89. Aksi görüşte bkz. ÇETINER, s. 205.

${ }^{152}$ Yarg. 12. HD, T. 23.11.2001, E. 2001/17448, K. 2001/19796 (“Bu halde alacaklı birbirinden bağımsız ipotek hakkına sahip olup, dilediği taşınmazın satışı ile paraya çevrilmesini isteyebilir.”); AKİPEK/AKINTÜRK/ ATEŞ, s. 762; KURŞAT, s. 401-402; KÖPRÜLÜ/ KANETİ, s. 295.

153 GÜRSOY, s. 21.

${ }^{154}$ KURŞAT, s. 401-402; SAYMEN/ELBİR, s. 583; GÜRSOY/EREN/CANSEL, s. 1035.

155 Yarg. 12. HD, T. 23.11.2001, E. 2001/17448, K. 2001/19796 (“Bu tür ipoteklerde alacak bölünmeyip bütünlüğ̈nü koruduğu halde rehin yükü taşınmazlara dă̆ıtılmıştır.”); SCHMID-TSCHIRREN (2016), Art. 798 N 14; SCHMID-TSCHIRREN (2015), Art. 798 N 18; LEEMANN, Art. 798 N 48; SCHMID/HÜRLIMANN-KAUP, N 1520; OĞUZMAN/ SELİÇİ/OKTAY-ÖZDEMİ, N 3216; AKIPEK/AKINTÜRK/ATEŞ, s. 761; DAVRAN, s. 
paraya çevirme talebinin tüm taşınmazlara birden yönetilmek zorunda olması da bunu doğrular ${ }^{156}$.

Toplu rehin bakımından TST m. 32/I/a-b hükümlerinde açıkça öngörülmesine rağmen, paylı rehinde rehne konu taşınmazlar arasında irtibat sağlanacağ 1 düzenlenmemiştir. Buna rağmen öğretide paylı rehne konu taşınmazlar arasında da bağlantı sağlanması gerektiği ve böylece taşınmazların tamamının paraya çevrilmesi gerekliliğinin yerine getirilmesini kolaylaştırılacağı savunulmaktadır ${ }^{157}$.

\section{Paylı Rehnin Paraya Çevrilmesi}

TMK m. 873/III hükmü uyarınca rehin hakkı sahibi, paylı rehinle yüklü tüm taşınmazların paraya çevrilmesini talep etmelidir ${ }^{158}$. Alacakl1, icra dairesine başvurarak İIK m. 145 vd. hükümlere göre "rehnin paraya çevrilmesi yoluyla takip" başlatır ${ }^{159}$. Toplu rehinden farklı olarak paylı rehinde icra dairesi, rehin konusu tüm taşınmazları paraya çeviriri ${ }^{160}$. Yine toplu rehinden farklı olarak paylı rehinde, taşınmazlardan birinin veya bazılarının paraya çevrilmesi, diğer taşınmazlar üzerinde rehin hakkının sona ermesine yol açamaz ${ }^{161}$.

Taşınmazın paraya çevrilmesinden elde edilen değer rehin yükünü aşarsa fazlalık, o taşınmazda arka sıralarda bulunan rehin hakkı sahiplerine, eğer arka sıralarda rehin hakkı bulunmuyorsa ya da bulunmakla birlikte onlar da tatmin edilmişse taşınmazın malikine verilir; diğer rehinli taşınmazlar üzerinde rehin hakk1 devam eden alacaklıya verilmez ${ }^{162}$. Bu sebeple de

26; KURŞAT, s. 399; KÖPRÜLÜ/KANETİ, s. 295; SİRMEN, s. 587; SARI, s. 1003.

${ }^{156}$ SCHMID-TSCHIRREN (2016), Art. 798 N 13; SCHMID-TSCHIRREN (2015), Art. 798 N 18; AKİPEK/ AKINTÜRK/ATEŞ, s. 762; SİRMEN, s. 588; SARI, s. 1004.

${ }^{157}$ KURŞAT, s. 402-403.

${ }^{158}$ DÜRR, Art. 798 N 124; LEEMANN, Art. 798 N 51; OĞUZMAN/SELİÇ̇̇/OKTAYÖZDEMIR, N 3216 dn. 39; GÜRSOY/EREN/CANSEL, s. 1035; KÖPRÜLÜ/KANETİ, s. 296; HELVACI, s. 232; KUNTALP, s. 288; KURŞAT, s. 423; ACAR, Belirlilik, s. 248; AYDIN ÜNVER, s. 87.

${ }^{159}$ GÜRSOY, s. 22 vd.; KURŞAT, s. 422. Borçlu iflas etmişse İIK m. 185 uyarınca icra dairesi yerine iflas dairesinin taşınmazları paraya çevireceği yönünde bkz. KURŞAT, s. 422-423.

${ }^{160}$ SİRMEN, s. 588; SARI, s. 1004; KÖPRÜLÜ/KANETİ, s. 296; AYDIN ÜNVER, s. 88.

${ }^{161}$ YHGK, T. 27.11.2002, E. 2002/12-823, K. 2002/1020: "Burada alacak tümlüğ̈̈nü korur, ancak taşınmazlardan her biri alacağın yalnız belirli bir bölümü için sorumlu olur. Bu durumda, rehinli taşınmazların her biri alacă̆ın ancak bir bölümüyle sorumlu olduğundan tümünün karşılanabilmesi için rehinin paraya çevrilmesinde rehinli tüm taşınmazların birlikte satılmast gerekir."

162 SCHMID-TSCHIRREN (2015), Art. 798 N 18; AKIPEK/AKINTÜRK/ATEŞ, s. 762; KUNTALP, s. 268; HELVACI, s. 232; ÇETINER, s. 205. 
taşınmazlardan birinin paraya çevrilmesinden rehin yükünden az para elde edilir ve rehin alacaklısı tam olarak tatmin olmazsa, eksik kalan miktar için diğer rehinli taşınmazlara başvurulamaz ${ }^{163}$.

\section{Rehinli Taşınmazın Sonradan Birden Fazla Taşınmazla Teminat Altına Girmesi}

Rehin kurulurken paylı rehin kararlaştırılabileceği gibi, rehinle yüklenmiş bir taşınmazın sonradan bölünmesi veya kat mülkiyetine çevrilmesi hâllerinde de paylı rehin ortaya çıkabiliir ${ }^{164}$. Taşınmazın bölünmesi hâlinde TMK m. 889/I, rehin yükünün taşınmazlara değerleri oranında paylaştırılmasını, yani paylı rehin kurulmasını öngörmüştür. Rehinli taşınmazın mülkiyetinin kat mülkiyetine dönüşmesi durumunda $\mathrm{KMK} \mathrm{m}$. 5/V uygulama alanı bulur ve bağımsız bölümler üzerinde, arsa payları oranında paylı rehin tesis edili1 ${ }^{165}$. Rehinli taşınmazın sonradan birden fazla taşınmazla teminat altına girmesi, paylı rehnin kurulması ve rehin yükünün taşınmazlara dağıtılması bakımından tekrardan kaçınmak adına toplu rehin kısmında ilgili başlık altında yapılmış açıklamalara yollama yapmakla yetiniyoruz ${ }^{166}$.

\section{Rehinli Taşınmazlardan Birinin veya Birkaçının Devri}

Her ne kadar toplu rehin hâlinde taşınmazlardan biri veya bazıları TMK m. 889 hükmü uygulama alanı bulsa da paylı rehnin arz ettiği özellikler bakımından anılan hüküm uygulanmaz. Bir başka ifadeyle, paylı rehin konusu taşınmazın devri hâlinde TMK m. 888 hükmü uygulanır. TMK m. 888/I hükmü, taraflarca aksi kararlaştırılmadıkça, rehinle yüklü taşınmazın devrinin borçlunun sorumluluğunda ve teminatta bir değişikliğe yol açmayacağını düzenlemiştir.

\section{SONUÇ}

Aynı alacağı teminat altına almak amacıyla birden çok taşınmaz üzerinde rehin kurulması, "birlikte rehin" olarak adlandırılmaktadır. TMK m. 855 uyarınca, birlikte rehin iki farklı şekilde tesis edilebilir. İstisnaî tür olarak öngörülen toplu rehin, TMK m. 855/I hükmünde düzenlenmiştir. Toplu rehinde, birden çok taşınmaz alacak miktarının tümünü teminat altına almak amaciyla rehnedilir. Bu durumda, rehin konusu birden fazla taşınmaz olsa da sadece bir rehin hakkı doğar. Toplu rehin; sadece rehne konu taşınmazların

\footnotetext{
${ }^{163}$ SCHMID-TSCHIRREN (2015), Art. 798 N 18; LEEMANN, Art. 798 N 49-50; DAVRAN, S. 26.

${ }^{164}$ KURŞAT, s. 394.

${ }^{165}$ GÜRSOY, s. 31; KURŞAT, s. 419; ÖZER, s. 61.

${ }^{166} \mathrm{Bu}$ hususta bkz. $§ 1 / \mathrm{VI}$.
} 
malikinin aynı kişi olması ya da maliklerin borçtan müteselsil olması hâllerinde kurulabilir.

TMK m. 855/II-III hükmünde düzenlenen ve birlikte rehin hâlinde kural olarak söz konusu olan paylı rehinde, teminat altına alınan alacak miktarı rehne konu taşınmazlar üzerinde paylaştııılır. Bu durumda, her bir taşınmaz üzerinde bağımsız birer rehin hakkı oluşur. Dolayısıyla her taşınmaz, kendi rehin yükü ile sorumludur. Paylı rehinde taraflar, taşınmazlar üzerindeki rehin yükünün paylaşımı konusunda anlaşma yapmalıdır. Böyle bir anlaşmanın bulunmaması durumunda, tapu müdürü rehin yükü dağıtımını taşınmaz değerleri oranında re'sen yapar. Taraflar rehin yükü dağıtımı konusunda anlaşamadıkları veya tapu memurunun dağıtımını onaylamadıkları takdirde mahkemeye başvurabilirler.

Birlikte rehin türleri karşılaştırıldığında toplu rehnin alacaklı bakımından paylı rehne göre daha yararlı olduğu görülmektedir. Zira paylı rehinde alacaklı, her bir taşınmazdan sadece yüklü olduğu rehin miktarı kadar alacak elde edebildiği için alacağının tamamını elde edebilmesi bütün taşınmazların paraya çevrilerek yüklenmiş oldukları rehin yükü kadar meblağın elde edilmesine bağlıdır. Oysaki toplu rehinde tek bir taşınmazın paraya çevrilmesiyle dahi alacaklının tüm alacağını elde edebilmesi mümkündür. Hiç şüphesiz toplu rehnin alacaklı bakımından arz ettiği bu yararlı durum, borçlu bakımından tam tersi bir özellik taşır. Bu çerçevede rehin borçlusu bakımından paylı rehnin daha faydalı olduğu söylenebilir. Zira paylı rehinde, taşınmazın paraya çevrilmesi neticesinde rehin yükünden fazla bir meblağ elde edilse bile alacaklı sadece rehin yükü kadarını elde edebilir ve fazla miktar, rehinli taşınmaz malikine iade edilir.

\section{KAYNAKÇA}

ACAR, Faruk: Rehin Hukuku Dersleri, 2. Bası, Vedat Kitapçılık, İstanbul, 2017. (ACAR, Rehin)

ACAR, Faruk: Rehin Hukukunda Taşınmaz Kavramı ve Özellikle Belirlilik İlkesi, 2. Basım, Vedat Kitapçılık, İstanbul, 2017. (ACAR, Belirlilik)

AKİPEK, Jale/AKINTÜRK, Turgut/ATEŞ, Derya: Eşya Hukuku, 2. Baskı, Beta Basım, İstanbul, 2018.

AYDIN ÜNVER, Tülay: "Birden Fazla Taşınmaz Üzerinde Toplu Rehin Kurulması", Medeni Hukuk Alanındaki Güncel Yargıtay Kararlarının Değerlendirilmesi Sempozyumları Cilt 1 Eşya Hukuku (20 Ekim 2016), On İki Levha Yayıncılık, İstanbul, 2017, s. 85-102. 
BENGİSU, Hande: "Birden Fazla Taşınmaz Üzerinde Kurulan İpoteğin Paraya Çevrilmesinde Taşınmazların Satışına İlişskin Sorunlar”, İstanbul Barosu Dergisi, Cilt 83, Y11 2009, Say1 4, s. 1879-1920.

ÇETINER, Bilgehan: Taşınmaz Teminatı, Filiz Kitabevi, İstanbul, 2015.

DAVRAN, Bülent: Rehin Hukuku Dersleri, Fakülteler Matbaası, İstanbul, 1972.

DÜRR, David: Kommentar zum schweizerischen Zivilrecht, Band IV Sachenrecht, Teilband 2b Das Grundpfandrecht, Erste Lieferung Systematischer Teil und Art. 793-804 ZGB, 2. Auflage, Schulthess Verlag, Zürich/Basel/Genf, 2009. (Herausgeber: GAUCH, Peter/SCHMID, Jörg)

FASEL, Urs: Handkommentar zum Schweizer Privatrecht, Sachenrecht, Art. 641-977 ZGB, 3. Auflage, Schulthess Verlag, Zürich/Basel/Genf, 2016. (Herausgeber: BREITSCHMID, Peter/JUNGO, Alexandra)

GÖKTÜRK, Hüseyin Avni: Türk Medenî Hukuku Dördüncü Kitap, Aynî Haklar, Güney Matbaacılık ve Gazetecilik, Ankara, 1949.

GÜNEL, M. Cahit: “Taşınmaz Rehninin Alacak Bakımından Kapsamı”, Prof. Dr. Özer Seliçi’ye Armağan, Seçkin Yayıncılık, İstanbul, 2006, s. 247-266.

GÜRSOY, Kemal Tahir: Birden Ziyade Gayrimenkulün Aynı Borç İçin İpotek Edilmesi ve Uygulamada Ortaya Çıkan Sorunlar, Türkiye Bankalar Birliği Yayınları, Ankara, 1978.

GÜRSOY, Kemal Tahir/EREN, Fikret/CANSEL, Erol: Türk Eşya Hukuku, Sevinç Matbaası, Ankara, 1978.

HATEMI, Hüseyin/SEROZAN, Rona/ARPACI, Abdülkadir: Eşya Hukuku, Filiz Kitabevi, İstanbul, 1991.

HELVACI, İlhan: Eski Medenî Kanunumuzla Karşılaştırmalı Olarak Türk Medenî Kanununa Göre Sözleşmeden Doğan İpotek Hakkı, On İki Levha Yayınc1lık, İstanbul, 2008.

HRUBESCH-MILLAUER， Stephanie/GRAHAM-SIEGENTHALER， Barbara/ ROBERTO, Vito: Sachenrecht, 5. Auflage, Stämpfli Verlag, Bern, 2017.

KÖPRÜlÜ, Bülent/KANETİ, Selim: Sınırlı Aynî Haklar, 2. Bası, Fakülteler Matbaası, İstanbul, 1983.

KUNTALP, Erden: “Aynı Alacak İçin Birden Çok Taşınmazın Rehni”, Yiğit Okur'a Armağan, Galatasaray Üniversitesi Yayınları, İstanbul, 1998, s. 265-293.

KURŞAT, Zekeriya: “Birlikte Rehin”, Prof. Dr. Özer Seliçi’ye Armağan, Seçkin Yayıncılık, Ankara, 2006, s. 393-426. 
LEEMANN, Hans: Kommentar zum Schweizerischen Zivilgesetzbuch, Band IV, Sachenrecht, II. Abteilung, Art. 730-918 ZGB, Verlag von Stämpfli \& Cie., Bern, 1925.

MARCHAND, Sylvain: Commentaire Romand, Code civil II, (Art. 457-977 CC, Art. 1-61 Tit. fin. CC), Helbing Lichtenhahn Verlag, Bâle, 2016. (Edité par: PICHONNAZ, Pascal/ FOËX, Bénédict/PIOTET, Denis)

OĞUZMAN, M. Kemal/SELİÇİ, Özer/OKTAY-ÖZDEMİR, Saibe: Eşya Hukuku, 19. Bask1, Filiz Kitabevi, İstanbul, 2016.

ÖZER, M. Tolga: Taşınmazların Birlikte Rehni (Aynı Alacağı Teminat Altına Almak İçin Birden Fazla Taşınmazın Rehni), Filiz Kitabevi, İstanbul, 2015.

SARI, Suat: “Taşınmaz Rehninde Belirlilik (Muayyenlik) İlkesi”, Prof. Dr. M. Kemal Oğuzman'ın Anısına Armağan, Beta Basım Yayın, İstanbul, 2000, s. 963-1011.

SAYMEN, Ferit H./ELBİR, Halid K.: Türk Eşya Hukuku (Aynî Haklar), Hak Kitabevi, İstanbul, 1954.

SCHMID, Jörg/HÜRLIMANN-KAUP, Bettina: Sachenrecht, 5. Auflage, Schulthess Verlag, Zürich/Basel/Genf, 2017.

SCHMID-TSCHIRREN, Christina: Basler Kommentar, Zivilgesetzbuch II (Art. 457-977 ZGB, Art. 1-61 SchlT ZGB), 5. Auflage, Helbing Lichtenhahn Verlag, Basel, 2015. (Herausgeber: HONSELL, Heinrich/VOGT, Nedim Peter/GEISER, Thomas) [SCHMID-TSCHIRREN (2015)]

SCHMID-TSCHIRREN, Christina: Orell Füssli Kommentar, ZGB Kommentar Schweizerisches Zivilgesetzbuch, 3. Auflage, Orell Füssli Verlag, Zürich, 2016. (Herausgeber: KOSTKIEWICZ, Jolanta Kren/WOLF, Stephan/ AMSTUTZ, Marc/ FANKHAUSER, Roland) [SCHMID-TSCHIRREN (2016)]

SCHUMACHER, Rainer: Das Bauhandwerkerpfandrecht, 3. Auflage, Schulthess Verlag, Zürich/Basel/Genf, 2008.

SEROZAN, Rona: “Taşınmaz Rehni”, İstanbul Üniversitesi Hukuk Fakültesi Mecmuası, Cilt LXIV, Y1l 2006, Sayı 2, s. 301-324.

SİRMEN, A. Lâle: Eşya Hukuku, 6. Baskı, Yetkin Yayınları, Ankara, 2018.

TEKINAY, Selâhattin Sulhi: Menkul Mülkiyeti ve Sınırlı Aynî Haklar (Eşya Hukuku II/3), Filiz Kitabevi, İstanbul, 1994.

TOPALOĞLU, Mustafa: Maden Hukuku, Karahan Kitabevi, İstanbul, 2011. 
TUOR, PETER/SCHNYDER, BERNHARD/SCHMID, JÖRG/JUNGO, ALEXANDRA: Das Schweizerische Zivilgesetzbuch, 14. Auflage, Schulthess Verlag, Zürich, 2015.

WIELAND, Carl: Kanunu Medeni'de Aynî Haklar, İkinci Cilt, 2. Bası, Yeni Cezaevi Basımevi, Ankara, 1949 (Çeviren: Karafakıh, İsmail Hakkı).

\section{KISALTMALAR}

Abs. Absatz (Fikra)

Art. Artikel (Madde)

BGBB Bundesgesetz vom 4. Oktober 1991 über das das bäuerliche Bodenrecht

BGE Amtliche Sammlung der Entscheidungen des Schweizerischen Bundesgerichts

bkz. bakınız

dn. dipnot

E. Esas (Yargıtay kararları için)

E. Erwägung (Gerekçe, İsviçre Federal Mahkemesi kararları için)

eTMK 17.02.1926 tarih ve 743 say1l (Eski) Türk Kanunu Medenîsi

eTST 18.05.1994 tarih ve 94/5623 sayılı Bakanlar Kurulu Kararı ile yürürlüğe konulan (Eski) Tapu Sicili Tüzüğü

HD Hukuk Dairesi (Yargıtay kararları için)

IIIK $\quad$ 09.06.1932 tarih ve 2004 say11 İcra ve İflâs Kanunu

K. Karar (Yargıtay kararları için)

KMK 23.06.1965 tarih ve 634 say1lı Kat Mülkiyeti Kanunu

krş. karşılaştırınız

m. madde

MadK $\quad 04.06 .1985$ tarih ve 3213 say1l Maden Kanunu

N Note, Randnote, Randnummer (Kenar Notu)

s. sayfa

T. Tarih (Yargıtay kararları için)

TBK 11.01.2011 tarih ve 6098 sayılı Türk Borçlar Kanunu

TMK 22.11.2001 tarih ve 4721 sayılı Türk Medenî Kanunu

TMKYK 03.12.2001 tarih ve 4722 say1l Türk Medenî Kanununun Yürürlüğ̈̈ ve Uygulama Şekli Hakkında Kanun

TSHK 14.10.1983 tarih ve 2920 sayılı Türk Sivil Havacıllk Kanunu 
TST 22.07.2013 tarih ve 2013/5150 sayılı Bakanlar Kurulu Kararı ile yürürlüğe konulan Tapu Sicili Tüzüğü

TTK 13.01.2011 tarih ve 6102 sayılı Türk Ticaret Kanunu

tZGB Türkisches Zivilgesetzbuch vom 22. November 2001

vd. ve devamı

Yarg. Yargitay

YHGK Yargitay Hukuk Genel Kurulu Kararı

ZGB Schweizerisches Zivilgesetzbuch vom 10. Dezember 1907 